
EDITOR'S
CHOICE

\title{
Apoptosis and cancer: mutations within caspase genes
}

\author{
S Ghavami, ${ }^{1,2,3}$ M Hashemi, ${ }^{4}$ S R Ande, ${ }^{5}$ B Yeganeh, ${ }^{6}$ W Xiao, ${ }^{5}$ M Eshraghi, ${ }^{5,6}$ C J Bus, ${ }^{7}$ \\ K Kadkhoda, ${ }^{8}$ E Wiechec, ${ }^{9}$ A J Halayko, ${ }^{1,2,3}$ M Los $^{7}$
}

${ }^{1}$ Department of Physiology, University of Manitoba, Winnipeg, Manitoba, Canada; ${ }^{2}$ National Training Program in Allergy and Asthma, University of Manitoba, Winnipeg, Manitoba, Canada; ${ }^{3}$ Biology of Breathing Group, Manitoba Institute of Child Health, Winnipeg, Manitoba, Canada; ${ }^{4}$ Department of Clinical Biochemistry, and Cellular Molecular Research Centre, Zahedan University of Medical Sciences, Zahedan, Iran; ${ }^{5} \mathrm{MICB}$, CancerCare Manitoba,

Winnipeg, Manitoba, Canada;

${ }^{6}$ Institute of Cardiovascular

Sciences, St Boniface General Hospital Research Centre, and Department of Biochemistry \& Medical Genetics, Faculty of Medicine, University of

Manitoba, Winnipeg, Canada;

${ }^{7}$ Interfaculty Institute for

Biochemistry, University of

Tübingen, Germany;

${ }^{8}$ Postgraduate medical

education, Faculty of Medicine, University of Manitoba and Diagnostic Services of Manitoba, Winnipeg, Manitoba, Canada;

${ }^{9}$ Department of Human Genetics, University of Aarhus, Aarhus, Denmark

Correspondence to:

Dr M Los, Interfaculty Institute of Biochemistry. University of

Tübingen, Hoppe-Seyler-Str. 4/ 402, D-72076 Tübingen,

Germany; mjelos@gmail.com

SG and MH contributed equally to the preparation of this article

Received 6 February 2009 Revised 24 March 2009 Accepted 13 April 2009

Published Online First

7 June 2009

\section{ABSTRACT}

The inactivation of programmed cell death has profound effects not only on the development but also on the overall integrity of multicellular organisms. Beside developmental abnormalities, it may lead to tumorigenesis, autoimmunity, and other serious health problems. Deregulated apoptosis may also be the leading cause of cancer therapy chemoresistance. Caspase family of cysteinyl-proteases plays the key role in the initiation and execution of programmed cell death. This review gives an overview of the role of caspases, their natural modulators like IAPs, FLIPs, and Smac/Diablo in apoptosis and upon inactivation, and also in cancer development. Besides describing the basic mechanisms governing programmed cell death, a large part of this review is dedicated to previous studies that were focused on screening tumours for mutations within caspase genes as well as their regulators. The last part of this review discusses several emerging treatments that involve modulation of caspases and their regulators. Thus, we also highlight caspase cascade modulating experimental anticancer drugs like cFLIP-antagonist CDDO-Me; clAP1 antagonists OSU03012 and ME-BS; and XIAP small molecule antagonists 1396-11, 1396-12, 1396-28, triptolide, AEG35156, survivin/Hsp90 antagonist shephedrin, and some of the direct activators of procaspase-3.

On average, one out of every four people will have cancer in their lifetime. Although inherited cancers account for only a small fraction of all tumours, most cancers are caused by a mix of hereditary and environmental factors. ${ }^{1}$ Identification of cancer stem cells in the majority of cancers suggests that the mutations are occurring within tissue stem cells, and cancer is both a consequence of uncontrolled proliferation, as well as disturbed differentiation. ${ }^{23}$ Genetic alterations often allow for verification of diagnosis and may even dictate the treatment approaches. Thus, cancer specific therapies based on specific genetic alterations (pharmacogenomics) have opened a new era of cancer treatment. ${ }^{4}$

Multicellular organisms employ two main mechanisms for the elimination of cells: necrosis and apoptosis. ${ }^{5}$ Necrosis may be triggered by the rupture of the plasmatic membrane and may be accompanied by formation of an inflammatory process. ${ }^{6}$ On the contrary, apoptosis involves a "cleaner" type of death, in which the chromatin is condensed; the DNA becomes fragmented forming vesicles known as "apoptotic bodies". These are rapidly phagocytosed by the macrophages with the result that the cell disappears without any inflammatory phenomena. ${ }^{7}$ Apoptosis induction might be achieved in several ways-for example, by promoting the expression of pro-apoptotic factors while reducing the expression of antiapoptotic factors only in the tumour cells, or by means of the infection of viral particles that act specifically within the transformed cells. ${ }^{8}$

In mammals, apoptosis can be initiated by three different pathways: (1) the extrinsic pathway, which can be triggered by ligation of death receptors and subsequent caspase- 8 activation; (2) the intrinsic pathway, which is initiated by cellular stress followed by activation of caspase-9; or (3) the granzyme B pathway, where the cytotoxic cell protease granzyme $B$ is delivered to sensitive target cells. Each of these pathways converges to a common execution phase of apoptosis that requires proteolytic activation of caspases-3 and/or -7 from their inactive zymogens. ${ }^{9}{ }^{10}$ Biochemically, the main features of apoptosis include caspase cascade activation and DNA fragmentation. ${ }^{11}$ Mitochondria also play a key role in mediating apoptosis induced by diverse stimuli. They release pro-apoptotic proteins (cytochrome c, Smac, Omi, AIF, and EndoG) whose release into the cytosol is regulated by proteins belonging to the Bcl2 family.

\section{EXTRINSIC AND INTRINSIC APOPTOSIS PATHWAY}

The receptor triggered or extrinsic apoptotic pathway was the first one to be described (fig 1). The receptors triggering this pathway are located in the cell membrane and they are activated by extracellular ligands. Typical death receptors are Fas (fibroblast associated antigen, also called Apo-1 or CD95) and tumour necrosis factor receptor (TNFR) 1; they belong to TNF-R family and contain a cytosolic death domain (DD). Ligation of death receptor causes formation of death inducing signalling complex (DISC) ${ }^{12}{ }^{13}$ in which the adaptor proteins FADD and/or TRADD bind with their death domain (DD) to a DD in the cytoplasmic region of the receptors. ${ }^{14}$ The receptor induced pathway leads to the recruitment of caspase-8 or 10 (initiator caspases) to the DISC. ${ }^{15}$ The activated caspase then proteolytically activates downstream effector caspases (also called executioner caspases) that degrade cellular targets. In accordance with a pivotal role of FADD and caspase- 8 in CD95- or TRAIL induced cell death, mice or cell lines deficient in these molecules are completely protected from the apoptotic action of TRAIL or CD95L. ${ }^{16-18}$ Activated caspase- 8 then directly cleaves pro-caspase- 3 or other executioner caspases, eventually leading to the apoptosis. Caspase- 8 can also cleave the BH3-only protein $\mathrm{Bid}$. The resulting truncated $\mathrm{Bid}(\mathrm{tBid})$ then moves to the mitochondria and induces cytochrome 


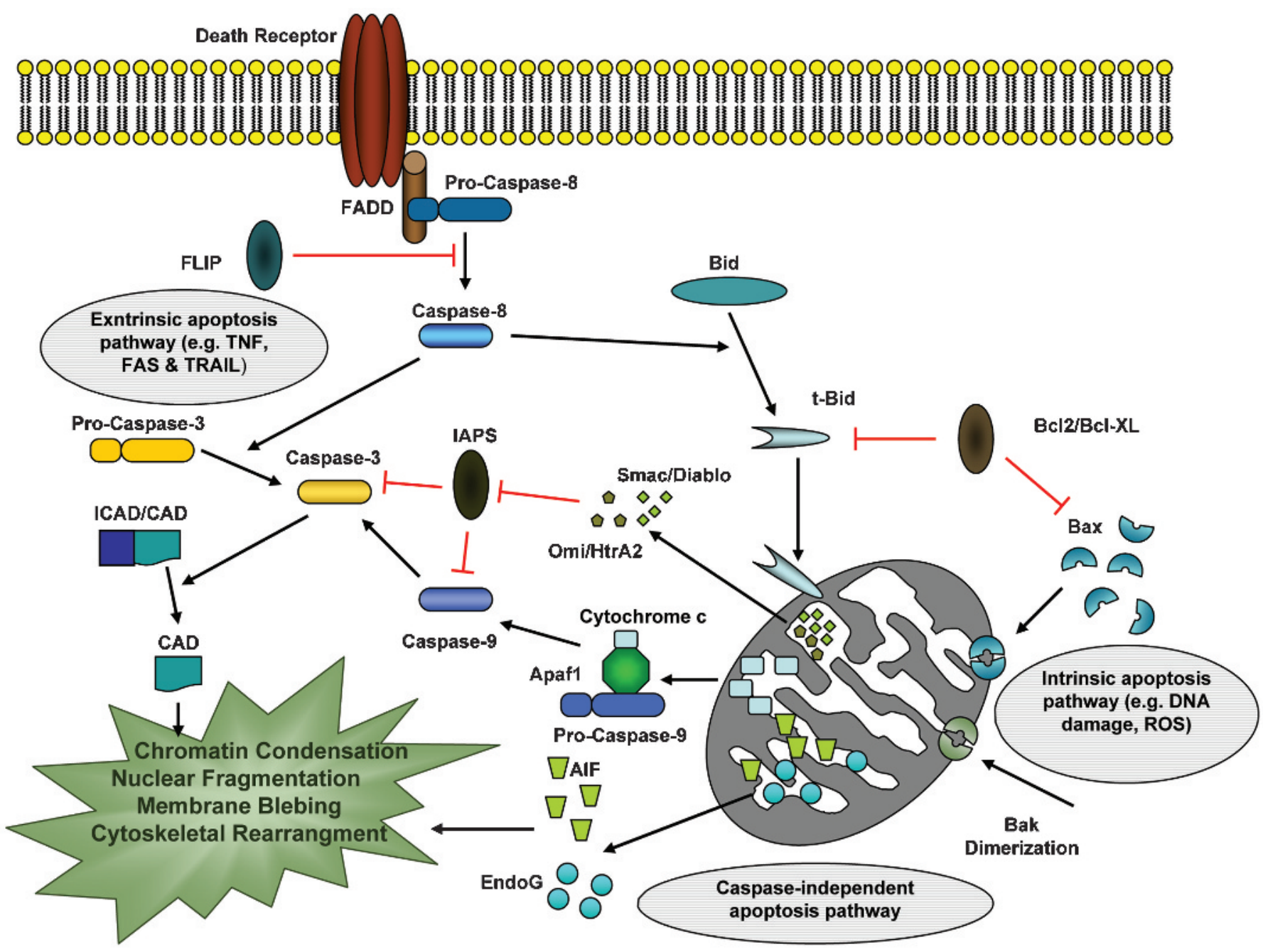

Figure 1 The molecular mechanisms of apoptosis. Apoptosis pathways can be initiated via different stimuli-that is, at the plasma membrane by death receptor ligation (extrinsic pathway) or at the mitochondria (intrinsic pathway). Stimulation of death receptors results in receptor aggregation and recruitment of the adaptor molecule Fas-associated protein with death domain (FADD) and caspase-8. Upon recruitment, caspase-8 becomes activated and initiates apoptosis by direct cleavage of downstream effector caspases. Mitochondria are engaged via the intrinsic pathway, which can be initiated by a variety of stress stimuli, including ultraviolet (UV) radiation, $\gamma$-irradiation, heat, DNA damage, the actions of some oncoproteins and tumour suppressor genes (that is, p53), viral virulence factors, and most chemotherapeutic agents. Mitochondrial membrane permeabilisation is regulated by balance of opposing actions of proapoptotic and antiapoptotic Bcl2 family members (Bax, Bak, Bcl2 and Bcl-XL, Mcl-1). Following mitochondrial permeabilisation, mitochondrial pro-apoptotic proteins like cytochrome c, Smac/Diablo, Omi/HtrA2 (caspase dependent), AlF, and Endo G (non-caspase-dependent) release via transmembrane channels across the mitochondrial outer membrane (see main text for more details). CAD, caspase activated DNase; FAS, fibroblast associated antigen; ICAD, inhibitor of CAD; ROS, reactive oxygen species; TNF, tumour necrosis factor; TRAIL, TNF related apoptosis inducing ligand.

c release, leading to activation of caspase-9 and caspase-3. DISC signalling can be inhibited by expression of c-FLIP, a physiologic dominant negative caspase-8 that leads to the formation of a signalling inactive DISC. ${ }^{19}$

The intrinsic or mitochondrial pathway is activated by a variety of extra- and intracellular stresses, including oxidative stress, irradiation, and treatment with cytotoxic drugs (fig 1). ${ }^{20-22}$ Unlike the death receptor dependent pathway, the mitochondria dependent pathway is mediated by Bax/Bak insertion into mitochondrial membrane, and subsequent release of cytochrome $\mathrm{c}$ from the mitochondrial inter-membrane space into the cytosol. ${ }^{23}$ Anti-apoptotic Bcl-2 family members, such as Bcl2 and $\mathrm{Bcl}-\mathrm{XL}$, prevent cytochrome $\mathrm{c}$ release, presumably by binding and inhibition of Bax and Bak. BH3-only proteins, such as Bid and Bim, contribute to the pro-apoptotic function of Bax or Bak by inducing homo-oligomerisation of these proteins. Cytochrome $\mathrm{c}$ then binds to the Apaf1 and together with
(d)ATP causes recruitment of pro-caspase-9 to the complex. ${ }^{24-26}$ The formed multi-protein complex is called apoptosome, which contains several units of Apaf1 and other above molecules and, depending on the isolation method, it has between $700 \mathrm{kBa}-$ $1.4 \mathrm{mBa}^{27-31}$ Activated caspase- 9 in turn activates caspase- 3 and initiates the proteolytic cascade. ${ }^{32}$ In addition to cytochrome c, mitochondria release a large number of other polypeptides, including AIF, ${ }^{33}$ Endo G, second mitochondrial activator of caspases (Smac/DIABLO) ${ }^{34}$ and $\mathrm{HtrA} 2 / \mathrm{Omi}^{35}$ from the intermembrane space. Smac/Diablo and Omi/HtrA2 promote caspase activation through neutralising the inhibitory effects of inhibitor of apoptosis proteins (IAPs), ${ }^{36}$ while AIF and endonuclease $\mathrm{G}$ cause DNA damage and condensation. ${ }^{37}$

\section{CASPASE FAMILY}

The first identified caspase, caspase-1, a homologue of CED-3, was actually interleukin- $1 \beta$ processing enzyme (ICE), originally 
discovered in totally different biologic context ${ }^{38}{ }^{39}$ (see below). Overexpression of ICE may induce or sensitize to apoptosis, ${ }^{38}$ therefore it was suggested that mammalian caspases may have an essential apoptotic functions as CED-3 in Caenorhabditis elegans ( $C$ elegans) cells. The official nomenclature names 14 caspases in mammals. ${ }^{19}$ Caspase-1, -10 , and -14 were found in human. ${ }^{40}$ Caspase-13 was later proved to be a bovine homologue of human caspase- $4 .{ }^{42}$ Caspase-11 and -12 are murine homologue enzymes of human caspase- 4 and $-5 .{ }^{43}$ Not all the caspases are involved in programmed cell death, and not all forms of cell death require caspases. Indeed, some caspases are crucial for apoptosis, some are not necessary, and most caspases have functions other than just take part in executing apoptosis, like cell survival, proliferation, differentiation or inflammation. ${ }^{44-46}$

The function of caspase is very closely related to its structure. Different caspases show different substrate preferences, although aspartate at P1 position is universally required for all caspase substrates. Some caspases have long prodomains containing special motif such as DED (caspase-8 and -10), and caspase recruitment domains (CARD) (caspase-1, -2, -4, -5, -9, 11 and -12), which allow for interactions with other proteins, and link with signalling pathways.

\section{Mechanisms of caspase activation}

Caspases are synthesised as a single chain of inactive zymogens, consisting of four domains: an $\mathrm{N}$-terminal prodomain of variable length, a large subunit with a molecular weight of about $20 \mathrm{kDa}$, a small subunit $(\sim 10 \mathrm{kDa})$, and a linker region connecting these catalytic subunits. ${ }^{47}$ The linker region is missing in some family members. Proteolytic cleavage of the caspase precursors results in the separation of large and small subunits with the production of a hetero-tetrameric complex (the active enzyme) consisting of two large and two small subunits. ${ }^{48}$ Caspases differ in the length and in the amino acid sequence of their $\mathrm{N}$-terminal prodomain. The long prodomain (more than 90 amino acid residues) contains one of two modular regions essential for the interaction with adaptor proteins. These modules contain DED or CARD. Hydrophobic protein interactions are mainly achieved via DED-DED contacts, whereas electrostatic interactions occur through CARDCARD contacts. ${ }^{47}$ Based on their proapoptotic functions, the caspases have been divided into two groups: initiators and effectors. First group of initiator (or apical) caspases (caspases-2, $-8,-9,-10$, and, probably, -11) activate the second-group of caspases (caspases-3, -6 , and -7). The effector (or downstream) caspases are able to directly degrade multiple substrates including the structural and regulatory proteins in the cell nucleus, cytoplasm, and cytoskeleton. ${ }^{49}$ In some cases, initiator caspases can also function as effector caspases; this activity helps to amplify a suicide signal in the cell whose death pathways have been only weakly initiated. Furthermore, the activation of effector caspases can not only be caused by initiator caspases, but also by other, non-caspase proteases, including cathepsins, calpains, and granzymes. Caspase- 1 and caspase- $4,-5$ have similar structures and are predominantly involved in the maturation of proinflammatory cytokines. However, significant bodies of experimental evidence exist that indicate a redundant/accessory role of these caspases in apoptosis. $^{38} 50$ The caspase proteolytic signalling cascades are interconnected and due to overlapping substrate specificity they are also partially redundant. As a result, the apoptotic signal can be significantly amplified. A number of cellular and viral caspase inhibitors exist that may prevent both initiation and amplification of the apoptotic signal within the proteolytic cascade. ${ }^{47}$ Below, we briefly introduce selected caspases.

\section{Caspase-2}

Caspase-2 is the second identified caspase. It contains a CARDdomain and recruit multi-protein complex "PIDDosome2 through CARD binding with RAIDD (RIP associated ICH-1/ ECD3 homologous protein with a death domain). ${ }^{51}$ The adaptor proteins RAIDD and PIDD (p53 induced protein with death domain) in this complex are essential components for the activation for caspase- 2 . $^{52}$ The function of capase- 2 is still poorly understood. While containing the long prodomain and being able to respond to a variety of apoptotic stimuli, ${ }^{53}$ and RAIDD mediated interaction with Fas, ${ }^{43}{ }^{54}$ it also bears some characters unlike an initiator. The substrate preference of it is more close to caspase- 3 and -7 , and it can even be activated by caspase- 3 , a downstream executioner. One more unique feature of caspase- 2 is the localisation to the nucleus and the Golgi apparatus in addition to cytosol. ${ }^{55-57}$ However, caspase-2 appears to act upstream of mitochondrial permeabilisation by cleaving and activating Bid, and plays an important role for DNA damage induced apoptosis. ${ }^{58-60}$ In response to genotoxic stress, the activation of either caspase- 2 or NF- $\kappa \mathrm{B}$ is controlled by different isoforms of PIDD, and will respectively lead cell to apoptosis or survival. ${ }^{61}$ However, in caspase- $2 \mathrm{KO}$ animal models, caspsase-2 is not really essential for most physiological cell deaths. A recent study demonstrated that disruption of caspase-2 has a significant impact on mouse aging, suggesting that caspase-2 deficiency compromised the animal's ability to clear oxidative damaged cells. ${ }^{6}$ Caspase- 2 may have more distinctive properties, and understanding the function of caspase- 2 is challenging. In a T-2 toxin induced apoptosis model, caspase- 2 activation is observed earlier than all the other caspases, and caspase- 2 might even affect caspase- 8 activation. ${ }^{63}$

\section{Caspase-8}

The function of caspase- 8 is well established. It is essential for the extrinsic cell death pathways initiated by the TNF family members. ${ }^{64}$ Death receptors will recruit the DISC upon binding specific TNF family ligands and trimerisation. Procaspase-8 can be recruited into this complex via the adaptor protein FADD. The dimerised, or trimerised, procaspase- 8 molecules in the DISC are activated through reciprocal cleavage. Activated caspase-8 then initiates downstream apoptotic cascade by cleaving caspase-3, caspase-7 or Bid. ${ }^{65-67}$ The activated caspase8 can also activate NF- $\mathrm{KB}$ and regulate lymphocyte proliferation. In proliferating cells, caspase-8 remains largely unprocessed, and becomes only weakly activated, while in FasL induced apoptosis, caspase- 8 processing and strong activation is observed. The key protein for regulating caspase- 8 activation level is c-FLIP ${ }_{\mathrm{L}}$, a caspase-8-like molecule that lacks caspase activity. ${ }^{69}$ In the absence of $\mathrm{c}-\mathrm{FLIP}_{\mathrm{L}}$, the dimerisation or trimerisation of procaspase- 8 leads to full processing and activation of procaspase- 8 molecules. At low concentrations of c-FLIP ${ }_{L}$, procaspase-8 preferably forms heterodimers with cFLIP $_{\mathrm{L}}$. Then limited procaspase- 8 activation occurs and active heterodimers remain associated with the DISC complex. Depending on the specific subset of substrates that is cleaved, either apoptosis or NF- $\mathrm{BB}$ activation can ensue. At high

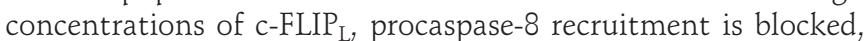
and $\mathrm{c}-\mathrm{FLIP}_{\mathrm{L}}$ cleavage is ensured by basal caspase- 8 activity, and subsequently NF- $\mathrm{KB}$ is activated. ${ }^{70}{ }^{71}$ In fact, besides function in TNF family induced apoptosis pathway, caspase- 8 also have 
other non-apoptotic functions such as in the macrophage differentiation, T cell, B cell and NK (natural killer) cell proliferation, and heart muscle development. ${ }^{40} 445$

\section{Caspase-9}

Caspase-9, the apical/initiator caspase within the apoptosome dependent cascade, has been extensively studied within the last 12 years. When the mitochondrial pathway is activated, cytochrome $\mathrm{c}$ is released from the mitochondria, and is recruited to the cytoplasmic receptor, Apaf1. ${ }^{72}{ }^{73}$ In the presence of dATP or ATP, cytochrome $\mathrm{c}$ and Apaf1 assemble into a complex called "apoptosome". Procaspase-9 then binds to Apaf1 through their CARD domain and becomes activated by reciprocal interaction with another procaspase-9.94 75 Then activated apoptosome bound caspase-9 cleaves and activates downstream enzyme, caspase-3.

\section{Caspase-10}

Like caspase-8, caspase-10 possesses two DEDs domain, which can be recruited to the same DISC as caspase- 8 and activated by death receptors. It can also cleave $\mathrm{Bid}$ and activate the mitochondrial pathway, suggesting that it may have an overlapping function with caspase-8. Despite the fact that it is highly homologous to caspase-8 both in structure and function, there is no mouse homologue of caspase- 10.437677 The association between caspase-10 gene dysfunction and an autoimmune disease ALPS-2, suggests that caspase-10 might have some different roles from caspase-8 in some cell types. However, the contributions of mutation to the disease are not conclusive. ${ }^{7678}$

\section{Caspase-12}

Caspase-12 is a murine caspase containing a CARD prodomain. Its human counterpart, also caspase-12, appears to be nonfunctional due to gene mutation. ${ }^{79}$ Unlike other caspases, caspase-12 is localised specifically to the endoplasmic reticulum (ER), and is a specific sensor responding to ER stress induced cell death. ${ }^{80}{ }^{81}$ In some cell types, under ER stress (usually caused by the accumulation of proteins), translocation of caspase-7 from the cytosol to the ER surface had been observed. Procaspase-12 is then activated as an initiator caspase, which can lead to procaspase- 9 activation. In this kind of caspase-9 mediated pathway, cytochrome $\mathrm{c}$ is not involved in the activation of procaspase-9. ${ }^{82-84}$ Murine caspase-12 shows homology to human caspase-4, which also had been proved to be involved in ER stress induced apoptosis, ${ }^{85}$ but it also plays a role in the immune system (see below).

\section{Caspase-1, $-4,-5,-11$}

Caspase-1, -4, -5, -11 formed the so-called "inflammatory caspases" group. Caspase-11 is a murine enzyme sharing lots of similarity with both caspase- 4 and -5 . It might be an ancestor gene to the other two caspase genes. ${ }^{46}$ These caspases are termed "inflammatory" as the main caspase-1 substrates identified to date are proIL-1 $\beta$ and proIL-18, two related cytokines that play critical roles in inflammation. ${ }^{46}{ }^{86}$ Targeted deletion of caspase-1 had no effect on animal development, and the embryonic fibroblasts and thymocytes from these mice are still very sensitive to various apoptotic stimuli. ${ }^{87}$ Caspase- $1^{-/-}$mice had, however, major defects in the production of mature IL-1 $\beta$ and impaired IL-1 $\alpha$ synthesis. Secretion of TNF and IL- 6 in response to LPS (lipopolysaccharide) stimulation was also reduced. In addition, macrophages from caspase- $1^{-/-}$mice were defective in LPS induced IFN- $\gamma$ production. ${ }^{88}$ Caspase- $1^{-/-}$mice were also resistant to the lethal effects of LPS. ${ }^{89}$ Thus, based on these murine models, the apoptotic function of caspase- 1 seems not to be as necessary as it is in inflammatory reaction. Since caspase- 4 and -5 are non-existent in mice, no direct data on their targeted disruption could be obtained. However, other caspases could also be involved in immunoregulation. It has been demonstrated that caspase- 11 can process caspase- 3 directly during ischaemia and septic shock in addition to regulating caspase- 1 activation. ${ }^{90}$

\section{Caspase-3, -6, -7}

These three effector caspases are highly homologous to each other. ${ }^{43}$ Their final functions are also similar in executing apoptosis. While caspase- 3 has been extensively studied, we have much less knowledge about caspase- 6 and -7 . None of them can fully control the execution of all the aspects of apoptosis. The contribution of each caspase to the cell death or dysfunction could be varied as well. In apoptotic cells, caspase-3 is the main executioner as it can be activated through both extrinsic and intrinsic signalling pathway, but it cannot be cleaved by caspase-2. ${ }^{91}$ Moreover, depletion of caspase-3 in cellfree apoptotic system cause inhibition of various downstream events while depletion of either caspase- 6 or caspase-7 do not show any effect. ${ }^{92}$ Caspase- 3 might be more important in most of downstream affairs, yet caspase- 6 and -7 may have distinct roles in specific pathways, such as the special function of caspase-7 in ER stress induced apoptosis. ${ }^{84}$

\section{MUTATIONS WITHIN THE CASPASE FAMILY AND CANCER}

Malfunction of apoptosis plays an important role in the pathogenesis of tumours. Tumour cell survival could be induced by inactivation of proapoptotic signalling or activation of antiapoptotic pathways. There are two major ways that could downregulate cancer cell apoptosis: (1) somatic and nonsomatic mutation and loss of expression of proapoptotic molecules; and (2) overexpression of apoptosis inhibitory molecules. ${ }^{93} 94$ Somatic mutations of apoptosis related genes affect several proteins. Mutations within caspase family proteases are not uncommon in malignancies. ${ }^{95}$ Here we focus on some frequent mutations within caspase family and their proposed role in different cancers.

\section{Mutations of caspase-8 gene and cancer}

Several reports show that caspase-8 is mutated in different types of cancers. Soung and colleagues ${ }^{94}$ screened gastric carcinomas (162 cases), breast carcinomas (93 caspase), nonsmall cell lung cancers (NSCLC) (185 cases), and 88 acute leukaemias (88 cases) for mutations within the caspase- 8 gene using single strand conformation polymorphism (SSCP). ${ }^{94}$ Interestingly, the caspase-8 mutations were mostly detected in gastric cancers but not in other cancer types. They found that the incidence of caspase- 8 mutation in gastric cancer is statistically higher than those of NSCLC, breast cancer, and acute leukaemias. Furthermore, all of the 13 mutations detected were in advanced gastric cancers but not in early gastric cancers. They reported that in 122 analysed advanced gastric cancers, 13 (10.1\%) cancer samples harboured caspase-8 mutations. The mutations consisted of three missense, one in-frame deletion, and five frameshift mutations in the coding sequences; two mutations in the initiation codon; three mutations in the introns; and one mutation in the $3 \mathrm{~V}$ untranslated region (table 1). The missense mutations detected in this study would result in the substitution of amino acids in the DED and the p10 
subunit. The frameshift mutations would result in premature terminations of caspase- 8 protein synthesis (table 1). They also proved that the caspase- 8 mutants were expressed well and the sizes of the detected mutants were matched with the predicted amino acid changes using in vitro translation and subsequent immunoblotting. They transfected 293T, 293, and HT1080 cells with observed caspase- 8 mutants. All mutants showed significant decrease of caspase- 8 activity in apoptosis induction compared with the wild type caspase-8 (except mutation 1427T $>$ C) ${ }^{94}$

In another study, the sensitivity of NSCLC and small cell lung carcinoma (SCLC) cells to the death receptor dependent cell death was investigated using cell lines derived from patients (they used the same concentrations of FasL and TRAIL in all experiments). ${ }^{96}$ While most NSCLC cells expressed detectable amounts of surface Fas, TRAIL-R1 and R2, they could not detect any surface death receptors in tested SCLC cell lines. They also reported that caspase- 8 protein precursor was undetectable in SCLC cells, but they do not elaborate on the nature of the defects in its expression. ${ }^{96}$

In another study, in breast cancer, D302H substitution was reported as a widespread variant in the caspase- 8 gene. ${ }^{97}$ However, a large multi-ethnic cohort study (MEC) that included over 215000 men and women in Hawaii and California, comprising predominantly self declared African Americans, Japanese Americans, native Hawaiians, Latinos and European Americans who were between the ages of 4575 years at enrolment, ${ }^{98} 99$ found no significant inverse association between $\mathrm{D} 302 \mathrm{H}$ variant in the caspase- 8 gene and risk of three common cancers (breast, colorectal, prostate) in pooled analyses. $^{98}$ They included groups of various ancestral backgrounds with very different disease risks and allele frequencies and consisted of large size and multiple cancer end points. Thus, the likelihood that the lack of significant association was attributable to bias or population stratification was unlikely. ${ }^{98}$

In another study, caspase-8 was investigated in meningioma. ${ }^{100}$ Their study was based on five case-control series that contributed to the international Interphone study. ${ }^{101}$ Briefly, the Interphone Study was a multicentre epidemiological casecontrol study to investigate whether mobile phone usage increases the risk of primary brain tumour (PBT) and malignant parotid gland tumours. The five case-control series of PBTs were assembled in the Thames regions of Southeast England the Northern UK including central Scotland, the West Midlands, West Yorkshire, and the Trent area; the Stockholm, Lund, Göteborg, and Umeå regions of Sweden; throughout Denmark; and in all regions of Finland except Northern Lapland and Åland. ${ }^{101}$ They could not find any significant increase in risk of meningioma and caspase-8 D302H. Their results were not consistent with other previously published data on meningioma that showed increased risk of caspase- $8 \mathrm{D} 302 \mathrm{H}$ variant on meningioma development. ${ }^{102}$ Again, this controversy might be due to population and ethnicity of the corresponding studies.

A case-control study in a Chinese population was done to evaluate the associations of caspase- 8 mutation and pancreatic cancer. ${ }^{103}$ This study consisted of 397 patients with pancreatic cancer and 907 controls. All subjects were Han Chinese. Genotypes of caspase-8 $-6526 \mathrm{~N}$ in/del polymorphisms were determined in this study. Caspase- $8-6526 \mathrm{~N}$ del/del genotypes showed a multiplicative joint effect with FasL and Fas in attenuating susceptibility to pancreatic cancer. The caspase-8 $6526 \mathrm{~N}$ in/del polymorphisms are summarised in table 2. Glioma accounts for about $80 \%$ of malignant primary brain tumours. ${ }^{104}$ Hypermethylation of caspase- 8 has been linked with glioblastoma multiforme relapse, ${ }^{105}$ suggesting that caspase- 8 may have a role in the development of glioma. It was found that $\mathrm{D} 302 \mathrm{H}$ was also a risk determinant of glioma. ${ }^{106}$

On the other hand, Sun et $a l^{107}$ identified a 6 bp deletion polymorphism $(-6526 \mathrm{~N} \mathrm{del})$ in the promoter of the CASP8 gene that abolishes the binding of Sp1 transcription factor and was associated with the decreased RNA expression in lymphocytes, and lower caspase-8 protein level. This deletion variant was found to be associated with an approximately $25 \%$ increased risk (per copy) of lung, oesophageal, stomach, colorectal, breast and

Table 2 Caspase-8 allelic and genotype frequencies in control and pancreatic cancer

\begin{tabular}{lll}
\hline Caspase-8 genotype & $\begin{array}{l}\text { Number of cases } \\
(\mathbf{n}=\mathbf{3 9 7})(\%)\end{array}$ & $\begin{array}{l}\text { Number of controls } \\
(\mathbf{n}=\mathbf{9 0 7})(\%)\end{array}$ \\
\hline CASP8 -652 6N ins $\rightarrow$ del $^{142}$ & & \\
ins/ins & $268(67.5)$ & $521(57.4)$ \\
ins/del & $111(28.0)$ & $323(35.6)$ \\
del/del & $18(4.5)$ & $63(7.0)$ \\
\hline
\end{tabular}

Table 1 Summary of caspase- 8 somatic mutation in gastric cancer

\begin{tabular}{|c|c|c|c|c|c|c|}
\hline Tumour type & $\begin{array}{l}\text { Total case } \\
\text { numbers }\end{array}$ & $\begin{array}{l}\text { Total cases } \\
\text { with caspase-8 } \\
\text { mutation }\end{array}$ & $\begin{array}{l}\text { Cases with } \\
\text { specific caspase-8 } \\
\text { mutation }\end{array}$ & Mutation site & Mutation type & $\begin{array}{l}\text { Nucleotide change (predicted amino acid } \\
\text { change) }\end{array}$ \\
\hline \multirow{13}{*}{$\begin{array}{l}\text { Gastric } \\
\text { carcinoma }^{94}\end{array}$} & \multirow[t]{13}{*}{162} & \multirow[t]{13}{*}{15} & 1 & Exon 1 (DED) & In-frame (deletion) & 249_251 delGGA (E84del) \\
\hline & & & 1 & Intron 2 & Substitution & IVS2 + 1G >A (Unknown) \\
\hline & & & 1 & Exon 1 & Insertion & 1_2insT (Unknown) \\
\hline & & & 1 & Exon 1 & Substitution & $1 \mathrm{~A}>\mathrm{G}$ (Unknown) \\
\hline & & & 1 & Exon 2 (DED) & Substitution (missense) & 409A >C M137L \\
\hline & & & 2 & Exon 3 (DED) & Deletion (frameshift) & $\begin{array}{l}492 \text { 493delTG (Frameshift after codon } 164 \text { and } \\
\text { stop at codon 178) }\end{array}$ \\
\hline & & & 1 & Exon 3 (in between DED/p20) & Substitution (missense) & $491 \mathrm{G}>\mathrm{A}(\mathrm{C} 164 \mathrm{Y})$ \\
\hline & & & 1 & Exon 7 (p10) & Insertion (frameshift) & $\begin{array}{l}1223 \text { 1224 insT (Frameshift after codon } 408 \\
\text { and stop at codon 438) }\end{array}$ \\
\hline & & & 1 & Exon 6 (p20) & Deletion (frameshift) & $\begin{array}{l}\text { 698delG (Frameshift after codon } 233 \text { and stop } \\
\text { at codon 237) }\end{array}$ \\
\hline & & & 2 & Intron 6 & Insertion & IVS6 + 47 insT (Unknown) \\
\hline & & & 1 & Exon 7 (p20) & Deletion (frameshift) & $\begin{array}{l}\text { 969_972 deICTAT (Frameshift after codon } 323 \\
\text { and stop at codon } 335 \text { ) }\end{array}$ \\
\hline & & & 1 & Exon 8 & Substitution (missense) & $1427 \mathrm{~T}>\mathrm{C}(\mathrm{F} 476 \mathrm{~S})$ \\
\hline & & & 1 & $3^{\prime}$-Untranslated region & Insertion & *43 insT (Unknown) \\
\hline
\end{tabular}


cervical cancer in a Chinese population (4938 cases and 4919 controls). ${ }^{107}$ This is, however, contradicted by analysis of four breast cancer case-control studies where data on various mutations including caspase- 8 mutation were analysed. ${ }^{108}$ These studies included: German Familial Breast Cancer Study (GFBCS), index patients of 1110 German BC families and 1108 control individuals, Sheffield Breast Cancer Study which included white Anglo-Saxon Sheffield residents, including 1212 pathologically confirmed patients with prevalent and invasive breast cancer recruited and 1184 unselected cancerfree women attending the Mammography Screening Service, ${ }^{109110}$ Gene Environment Interaction and Breast Cancer in Germany (GENICA) in which 1143 incident breast cancer cases and 1155 population controls were recruited from the Greater Bonn Region, Germany, ${ }^{111} 112$ and finally studies of Epidemiology and Risk Factors in Cancer Heredity (SEARCH) which included breast cancer and control subjects. ${ }^{113}$ They could not find any association between caspase- $8-6526 \mathrm{~N}$ del promoter polymorphism and breast cancer. Given this lack of association in Europeans, it was suggested that the functional caspase-8 $6 \mathrm{~N}$ del promoter variant may have an ethnicity specific effect due to different genetic backgrounds (Asians vs Europeans) and it could interpret the findings that Sun et al reported of the association of this polymorphism with breast cancer. ${ }^{107}$

Pancreatic cancer is one of the leading causes of cancer related death in the world. ${ }^{114}{ }^{115}$ Smoking, diabetes mellitus history, and, perhaps, alcohol drinking are risk factors for pancreatic carcinogenesis. ${ }^{116-119}$ However, only a part of exposed individuals develops pancreatic cancer in their lifespan, suggesting that genetic susceptibility factors also play a role in pancreatic carcinogenesis. It has been shown that pancreatic cancer cells often present non-functional CD95/Fas and aberrant expression of FasL, and this mechanism may contribute to the malignant and often rapid course of the disease. ${ }^{120-122}$ It is unclear if CD95/ Fas itself or downstream signalling molecules like caspase-8 are inactivated in these cases.

\section{Caspase-9 gene mutation and cancer}

Caspase-9 is a virtually ubiquitous protease, constitutively expressed in a variety of fetal and adult human tissues. ${ }^{123}{ }^{124}$ Mutational analysis of caspase-9 was performed in neuroblastoma tissues; however, no somatic mutation of caspase-9 in the tumours were found. ${ }^{125}$ In another study 180 gastric, 104 colorectal and 69 lung adenocarcinomas were randomly selected for the study. ${ }^{126}$ They isolated genomic DNAs from normal and tumour tissues of the same patients and studied the entire coding region with all splice sites of the caspase-9. Silent mutations were detected in two colorectal carcinomas and one gastric carcinoma. The mutations consisted of a G-to-A transition at nucleotide 261 (261G>A; S87S) in exon 2, a Gto-A transition at nucleotide 588 (588G $>\mathrm{A}$; S196S) in exon 4, and a G-to-A transition at nucleotide 1101 (1101G > A; L367L) in exon 8.

In a case-control study, lung cancer patients and age and gender matched healthy controls were investigated for caspase- 9 promoter polymorphism in lung cancer. ${ }^{127}$ All cases and controls were ethnic Koreans in this study and the cases included 210 (48.6\%) squamous cell carcinomas, 141 (32.6\%) adenocarcinomas, $73(16.9 \%)$ small cell carcinomas, and eight (1.9\%) large cell carcinomas. ${ }^{127}$ They observed a significant difference in the distribution of the $-2712 \mathrm{C}>\mathrm{T}$ genotypes between the cases and controls, but there was no significant difference in the distribution of genotypes between cases and controls for -
21263A $>$ G, -2905T>G, and -2293del. ${ }^{127}$ They reported that the -21263 GG genotype was associated with a significantly decreased risk of lung cancer compared with the -21263 AA or the combined $21263 \mathrm{AA}+\mathrm{AG}$ genotype. They also found that for the 2712C $>$ T polymorphism, individuals with at least one $712 \mathrm{~T}$ allele were at a significantly increased risk of lung cancer compared with those harbouring -712 CC genotype, and the risk of lung cancer increased with increasing numbers of $-712 \mathrm{~T}$ alleles. Their other finding showed that the $-905 \mathrm{~T}>\mathrm{G}$ and 293del polymorphisms were not significantly associated with the risk of lung cancer. ${ }^{127}$ Another interesting finding of this study was that caspase- 9 polymorphisms and their haplotypes interacted with tobacco smoking. They found that caspase-9 polymorphisms were significantly associated with the risk of lung cancer in the smokers but not in the non-smokers, which reflects a gene-environment interaction. Such an interaction is biologically plausible because smoking is a major risk factor for lung cancer. It was also found that the association between caspase-9 polymorphisms and the risk of lung cancer was statistically significant in the light smokers but not in the heavy smokers. Thus, the data indicate that an environmental carcinogen (components of cigarette smoke), if applied in larger quantities, may override genetic predisposition. ${ }^{128}{ }^{129}$ In another study, caspase-9 polymorphism was investigated in multiple myeloma in a case-control study (183 patients and 691 controls). ${ }^{130}$ Genotyping of the caspase- 9 single nucleotide polymorphism (SNP) [Ex5p32 G>A (rs1052576)] was done in this study. They found a protective association for the mentioned caspase- 9 polymorphism in multiple myeloma.

\section{Mutations within caspase- 3 and cancer risk}

Caspase- 3 is an effector caspase, and is activated by extrinsic and intrinsic cell death pathways. It plays a central role in the execution phase of cell apoptosis. ${ }^{28} 76131$ A caspase-3 mutation has been reported in the MCF-7 breast cancer cell line, ${ }^{132}$ suggesting the presence of caspase-3 mutation in human cancer tissues. There are several recent reports that have focused on the caspase-3 mutation in different cancers. Soung et al have investigated caspase- 3 somatic mutation in several cancers. ${ }^{133}$ They investigated 165 stomach carcinomas, 95 colon carcinomas, 76 breast carcinomas, 80 hepatocellular carcinomas, 181 non-small cell lung cancers, 28 multiple myelomas, 12 medulloblastomas, 15 Wilms' tumours, 12 renal cell carcinomas, 40 oesophagus carcinomas, 33 urinary bladder carcinomas, 33 laryngeal carcinomas, 129 non-Hodgkin lymphomas, and 45 acute leukaemias and compared healthy and malignant tissue from the same patients for caspase-3 somatic mutations. They did not observe any evidence of mutations in normal samples from the same patients and concluded that the mutations had risen somatically. ${ }^{133}$ The mutation data are summarised in table 3 , and show that caspase-3 was mutated in one case in stomach adenocarcinoma, one case in lung cancer, four cases in colon cancer, one case in hepatocellular carcinoma, and one case in multiple myeloma. The mutations consisted of six missense mutations, four silent mutations, two mutations in the introns, one mutation in the $5^{\prime}$-untranslated region, and one mutation in the $3^{\prime}$-untranslated region. Of the six missense mutations, two were predicted to involve the p17 large protease subunit and the other four to involve the $\mathrm{p} 12$ small protease subunit. Of note, two missense mutations in exon 6 showed an identical A to $T$ transversion at base pair 674 in unrelated individuals.

In other study, caspase-3 mutation was investigated in squamous cell carcinoma of the head and neck (SCCHN). This case-control analysis included 930 patients with histolo- 
Table 3 Summary of caspase-3 somatic mutation in different cancer

\begin{tabular}{|c|c|c|c|c|c|}
\hline Tumour type & $\begin{array}{l}\text { Total case } \\
\text { numbers }\end{array}$ & $\begin{array}{l}\text { Cases with } \\
\text { caspase-3 } \\
\text { mutation }\end{array}$ & Mutation site & Mutation type & $\begin{array}{l}\text { Nucleotide change (predicted } \\
\text { amino acid change) }\end{array}$ \\
\hline Adenocarcinoma-stomach ${ }^{133}$ & 165 & 2 & $\begin{array}{l}\text { Exon } 6 \text { ( } p 12 \text { protease subunit) } \\
\text { Intron } 4\end{array}$ & Silent & $\begin{array}{l}667 \mathrm{C} \rightarrow \mathrm{T} \text { (no change) } \\
\text { IVS4 }-64 \text { del A (no change) }\end{array}$ \\
\hline $\begin{array}{l}\text { Squamous cell carcinoma-lung and lung } \\
\text { adenocarcinoma }^{133}\end{array}$ & 181 & 4 & $\begin{array}{l}\text { Exon } 6 \text { ( } p 12 \text { protease subunit) } \\
\text { Exon } 6 \text { ( } p 12 \text { protease subunit) } \\
\text { Exon } 3 \text { ( } p 17 \text { protease subunit) } \\
\text { Exon } 5 \text { ( } p 12 \text { protease subunit) }\end{array}$ & $\begin{array}{l}\text { Silent } \\
\text { Missense } \\
\text { Missense } \\
\text { Missense }\end{array}$ & $\begin{array}{l}667 \mathrm{C} \rightarrow \mathrm{T} \text { (no change) } \\
674 \mathrm{~A} \rightarrow \mathrm{T}(\mathrm{O} 225 \mathrm{~L}) \\
278 \mathrm{G} \rightarrow \mathrm{T}(\mathrm{R} 93 \mathrm{~L}) \\
553 \mathrm{C} \rightarrow \mathrm{A}(\mathrm{H} 185 \mathrm{~N})\end{array}$ \\
\hline Adenocarcinoma- rectum & & & Exon 4 ( $p 17$ protease subunit) & Missense & $469 \mathrm{C} \rightarrow \mathrm{A}(\mathrm{L} 157 \mathrm{I})$ \\
\hline Adenocarcinoma- descending colon & & & Exon 4 (p17 protease subunit) & Silent & $579 C \rightarrow A(F 193 L)$ \\
\hline Adenocarcinoma- descending colon ${ }^{133}$ & & & Exon 6 ( $\mathrm{p} 12$ protease subunit) & Silent & $654 \mathrm{G} \rightarrow \mathrm{A}$ (no change) \\
\hline Hepatocellular carcinoma ${ }^{133}$ & 80 & 1 & $5^{\prime}$-untranslated region & & $-\mathrm{TC} \rightarrow \mathrm{T}$ (no change) \\
\hline Multiple myeloma ${ }^{133}$ & 28 & 1 & Intron 5 & & IVS $5+8 \mathrm{C} \rightarrow \mathrm{T}$ (no change) \\
\hline
\end{tabular}

gically confirmed SCCHN. All cases were non-Hispanic whites and had not received any radiotherapy or chemotherapy at the time of recruitment and blood donation. The 993 cancer-free subjects were recruited in the same time period, who were frequency matched to the cases by age, sex, and ethnicity. ${ }^{134}$ SCCHN is one of the most common cancers in the world. ${ }^{135}$ It is estimated that there were approximately 40566 new cases of SCCHN in the USA in 2007. ${ }^{114}$ They identified caspase- 3 transcriptional regulatory region (rs4647601:G>T, rs4647602:C>A, and rs4647603:G>A) polymorphisms in case and control subjects. ${ }^{134}$ The distribution of these polymorphisms in case and control group is shown in table 4. There was no statistically significant difference in the distributions of either allele or genotype frequencies of these three SNPs. However, when comparing with the GG genotypes of the caspase-3 rs4647601:G>T, they found an association of the caspase-3 rs4647601:TT genotype with an increased risk of SCCHN, and there was no association with any genotype of the caspase-3 rs4647602:C $>A$ and rs4647603:G $>A$ SNPs ( $>0.180$, $\mathrm{p}>0.547$ ). They also found evidence that caspase-3 rs4647601:TT genotype increased the risk of SCCHN in the subgroups of younger males, non-drinkers and never-smokers. ${ }^{134}$

\section{Caspase-7 mutations and oncogenesis}

Caspase-7 is another effector caspase that is comparatively important to caspase- 3 in apoptosis execution, especially in the

Table 4 Caspase-3 polymorphism in the squamous cell carcinoma of the head and neck

\begin{tabular}{lcc}
\hline Caspase-3 genotype & $\begin{array}{l}\text { Cases } \\
(\mathbf{n}=\mathbf{9 3 0})(\%)\end{array}$ & $\begin{array}{l}\text { Controls } \\
(\mathbf{n}=\mathbf{9 9 3})(\%)\end{array}$ \\
\hline CASP3 (rs4647601:G>T) $)^{134}$ & & \\
GG & $314(33.8)$ & $365(36.8)$ \\
GT & $435(46.8)$ & $463(46.6)$ \\
TT & $181(19.4)$ & $165(16.6)$ \\
GT+TT & $616(66.2)$ & $628(63.2)$ \\
CASP3 (rs4647602:C $>$ A) ${ }^{134}$ & & \\
CC & $802(86.2)$ & $833(83.9)$ \\
AC & $122(13.1)$ & $147(14.8)$ \\
AA & $6(0.7)$ & $13(1.3)$ \\
AC+AA & $128(13.8)$ & $160(16.1)$ \\
CASP3 (rs4647603:G $>A)^{134}$ & & \\
GG & $687(73.9)$ & $753(75.8)$ \\
GA & $223(24.0)$ & $223(22.5)$ \\
AA & $20(2.1)$ & $17(1.7)$ \\
GA+AA & $243(26.1)$ & $240(24.2)$ \\
\hline
\end{tabular}

cells with deficient or under-expressed caspase-3. ${ }^{136} 137$ As other protease family members, caspase- 7 is expressed as an inactive proenzyme, that upon processing generates a large p23 and a small p12 subunit. ${ }^{40}{ }^{138}$ Caspase-7 somatic polymorphisms were studied in some common cancers. Briefly, 33 SCCHN, 35 transitional cell carcinomas of urinary bladder, 50 oesophageal squamous cell carcinomas, 80 non-small cell lung cancers, 98 colon adenocarcinomas and five gastric adenocarcinomas were compared with corresponding normal cells from the same patients. ${ }^{139}$ The somatic polymorphism of caspase-7 in these patients is illustrated in table 5. Among the mutations of caspase-7 found in this study, one nonsense mutation (colon cancer, exon 2, $127 \mathrm{C}$ to $\mathrm{T}$ ) was identified in the coding regions of the large p23 subunit. The nonsense mutation was predicted to cause premature termination of protein synthesis, and hence resemble typical loss-of-function mutations. The $\mathrm{C}$ to $\mathrm{T}$ transition at bp 127 leads to a termination at codon 43, resulting in a protein that has a prodomain and a part of $\mathrm{p} 23$ large subunit. In addition, the Arg at amino acid 43 is conserved in caspase- 7 among the species of human, mouse and rat. ${ }^{139}$ This amino acid is also conserved in other caspases such as caspase- 3 , $-6,-8$ and $-9 .{ }^{139}$ The Arg- 43 of caspase- 7 is one of the constituting residues for substrate's $\mathrm{P} 1$ binding pocket, ${ }^{140}$ and it seems that alteration of the Arg-43 decreases the protease function of caspase-7. It was found that this mutant has a defect in induction of apoptosis. ${ }^{139}$

Mutations of inflammatory caspases $\mathbf{- 1 ,}, \mathbf{4}$, and $\mathbf{- 5}$ and cancer Pro-interleukin-1 $\beta$ and pro-interleukin-18 $\beta$ are the most important caspase- 1 substrates which play critical roles in inflammation. There are several reports that inflammation plays important roles in cancer. ${ }^{141}{ }^{142}$ Cancer cells produce many inflammatory mediators and interconnect with surrounding cells. ${ }^{142}$ Soung et al has recently investigated the probable role of

Table 5 Caspase-7 somatic mutations in different cancers

\begin{tabular}{|c|c|c|c|c|}
\hline Tumour type & $\begin{array}{l}\text { Total } \\
\text { case } \\
\text { numbers }\end{array}$ & $\begin{array}{l}\text { Cases with } \\
\text { caspase-7 } \\
\text { mutations }\end{array}$ & $\begin{array}{l}\text { Mutation } \\
\text { site }\end{array}$ & $\begin{array}{l}\text { Nucleotide change } \\
\text { (predicted amino acid } \\
\text { change) }\end{array}$ \\
\hline \multirow{2}{*}{$\begin{array}{l}\text { Colon } \\
\text { adenocarcinoma }^{139}\end{array}$} & \multirow[t]{2}{*}{90} & \multirow[t]{2}{*}{2} & Exon 2 & $127 \mathrm{C}$ to $\mathrm{T}$ (Arg 43 stop) \\
\hline & & & Exon 3 & $384 \mathrm{~A}$ to $\mathrm{G}$ (no change) \\
\hline $\begin{array}{l}\text { Oesophageal } \\
\text { squamous cell } \\
\text { carcinoma }^{139}\end{array}$ & 50 & 1 & Intron 1 & $\begin{array}{l}\text { IVS } 1 \text { C - } 3 \text { to T (splice } \\
\text { defect) }\end{array}$ \\
\hline $\begin{array}{l}\text { Laryngeal squamous } \\
\text { cell carcinoma }\end{array}$ & 33 & 1 & Exon 2 & $209 \mathrm{G}$ to $\mathrm{A}$ (Cys $70 \mathrm{Tyr}$ ) \\
\hline
\end{tabular}


inflammatory caspases in cancer. ${ }^{142}$ They identified somatic mutation for caspase-1, 4, and -5 in 337 patients with different cancers (103 colon carcinomas, 60 breast ductal carcinomas, 60 hepatocellular carcinomas, 54 gastric carcinomas, and 60 nonsmall cell lung cancers). They detected caspase- 1 mutations in two $(0.6 \%)$ of the 343 cancers, both in gastric carcinomas (54 samples) (3.7\%) (table 6). The mutations consisted of one missense mutation in exon $7(1034 \mathrm{~T}>\mathrm{A})$ and one substitution mutation in intron 2 (IVS2-3C>A). They could not find any significant correlation of the caspase- 1 mutations with histologic subtype of the gastric carcinomas. ${ }^{142}$ Caspase- 4 mutations were detected in two $(0.6 \%)$ of the 337 cancers, both in colon carcinomas (103 samples screened) (1.9\%) (table 6). They could not identify any significant association between tumour size, metastasis, location of the tumours, patients' sex/age, and recurrence and caspase- 4 mutations. ${ }^{142}$ Caspase- 5 mutations were detected in 15 (4.4\%) of the 337 cancers. According to the tumour types, mutations were detected in nine gastric carcinomas (16.7\%), four colon carcinomas (3.9\%), one invasive ductal breast carcinoma $(1.7 \%)$, and one lung adenocarcinoma $(1.7 \%)$. The caspase- 5 mutations consisted of nine mutations in exons, five mutations in introns, and one mutation in $5^{\prime}$ untranslated region (UTR). The nine mutations in the exons consisted of seven frameshift mutations in the $(A)_{10}$ repeat sequences in exon 2, one missense mutation, and one silent mutation. According to tumour subtypes in the gastric carcinomas, eight caspase-5 mutations were detected in advanced gastric carcinomas (18.2\%), while one mutation was observed in early gastric carcinoma (10.0\%). There was no significant association of the caspase- 5 mutation incidence with age/sex, stage, and histologic type of tumour. ${ }^{142}$

\section{CASPASES AND CASPASE INHIBITORS: POTENTIAL CLINICAL APPLICATIONS}

Since caspases play a central role in apoptosis and inflammation, they are attractive targets for diseases associated with uncontrolled cell proliferation as in cancer or autoimmune diseases. Thus, the controlled activation or inhibition of caspases offers an attractive means of therapeutic intervention. Below, we provide examples of such interventions, at various stages of implementation.

As indicated above, mutations within caspase family proteases are not uncommon in malignancies. ${ }^{95}$ Modulation of caspase activity for therapeutic purposes has been approached experimentally. Restoration of procaspase- 3 expression both in respective cell lines as well as in primary tumour cells increases their sensitivity towards anticancer therapies. On the other hand, inhibition of the expression of some caspases - that is, by antisense RNA strategies-makes such cells more resistant towards classical chemotherapy. ${ }^{143}$ Efforts are being made to gain better understanding of the mechanisms responsible for activation of the caspase cascade so that anticancer drugs could be designed that directly target caspase activation mechanism rather than causing cellular stress, which would then lead to cell death. ${ }^{144}$ Still, caspases may not be the critical determinants of tumour's sensitivity to cancer therapy (see below). Several studies show that tumour cells with a normal caspase activity are more responsive to anticancer-treatment, ${ }^{145}$ while some data indicate no correlation. ${ }^{146}$

Caspase inhibitors have been tested in other conditions besides cancer. For example, the development of intraepidermal blisters is a symptom of the autoimmune skin disease Pemphigus foliaceus caused by acantholysis and pathogenic autoantibodies against desmoglein 1 , and could be prevented by application of Ac-DEVD-cmk, a peptide based caspase-3/7 inhibitor, and BokD-fmk, a broad spectrum caspase inhibitor. ${ }^{147}$ A Chinese traditional medicine (Shenfu injection), which consists mostly of ginsenocides and aconitine, suppresses apoptosis during hypoxia/reoxygenation in cardiomyocytes by increasing Bcl-2 expression and decreasing caspase- 3 activity. ${ }^{148}$ Similarly, the treatment of tubular cell deletion in renal scarring with the pancaspase inhibitor Bok-D-fmk markedly prevented renal proximal tubular cell apoptosis induced by cisplatin (rat model). ${ }^{149}$

\section{c-FLIP and caspase-8}

In some malignancies as previously mentioned, the gene encoding for caspase- 8 is mutated or deleted or the expression of caspase- 8 is altered so that it cannot bind to FADD conferring resistance to TRAIL (TNF-related apoptosis-inducing ligand) mediated cell death. ${ }^{150}$ TRAIL is a member of TNF-superfamily and belongs to the type II trans-membrane family of proteins; however, physiologically, like TNF, it is mostly active in its soluble trimeric form. ${ }^{151}$ It induces apoptosis by binding to death receptors present on the target cells, namely TRAIL-R1/DR-4 and TRAIL-R2/DR-5. ${ }^{152}$ An interesting feature of TRAIL is that it induces apoptosis predominantly in cancer cells while sparing normal cells. ${ }^{153}$ For example, primitive neuro-ectodermal brain tumour cells are resistant to TRAIL mediated apoptosis due to the loss of expression of caspase- $8 .{ }^{154}$ Another example is human neuroblastoma malignancies that lack caspases-3 and -8, thereby resulting in resistance to standard chemotherapies. ${ }^{155}$

Table 6 Caspase-1, -4 , and -5 somatic mutations in different cancers

\begin{tabular}{|c|c|c|c|c|c|}
\hline Caspase & Tumour type & $\begin{array}{l}\text { Total case } \\
\text { numbers }\end{array}$ & $\begin{array}{l}\text { Cases with } \\
\text { mutation }\end{array}$ & Mutation site & Nucleotide change (predicted amino acid change) \\
\hline \multirow[t]{2}{*}{  } & Gastric carcinoma & 54 & 2 & Exon 7 (p10) & $1034 \mathrm{~T}>\mathrm{A}(\mathrm{M} 345 \mathrm{~K})$ \\
\hline & & & & Intron 2 & VS2-3C $>$ A (unknown) \\
\hline & & & & Exon 3 (p20) & $346 \mathrm{G}>\mathrm{T}(\mathrm{R} 116 \mathrm{I})$ \\
\hline Caspase- $5^{142}$ & NSCLC (adenocarcinoma) & 60 & 1 & Exon 4 (p20) & 629TNA (L2100) \\
\hline \multirow[t]{2}{*}{ Caspase- $5^{142}$} & Colon carcinoma & 103 & 4 & Exon 2 (CARD domain) & 153_154delAA (frameshift after codon 51 and stop at codon 68) \\
\hline & & & & Intron 6 & IVS $6-6 \mathrm{~T}>\mathrm{A}$ (unknown) \\
\hline \multirow[t]{3}{*}{ Caspase- $5^{142}$} & Gastric carcinoma & 54 & 9 & 5'-UTR (4 cases) & -21 -22AA (unknown) \\
\hline & & & & Exon 2 (CARD domain) (3 cases) & 154delA (frameshift after codon 51 and stop at codon 77) \\
\hline & & & & Exon 2 (CARD domain) & 153 154delAA (frameshift after codon 51 and stop at codon 68) \\
\hline Caspase- $5^{142}$ & Breast carcinoma & 60 & 1 & Exon 1 & $105 \bar{T}>C(N 35 N)$ \\
\hline
\end{tabular}


In some cases resistance to apoptotic cell death is associated with inactivation of caspase- 8 gene by methylation. ${ }^{156}$

Apart from the regulation of caspase- 8 expression, physiologic caspase- 8 inhibitors also exist. Cellular "FLICE-like inhibitory protein" (cFLIP) is a cytosolic FLICE/casapase-8 inhibitor that, depending on splice variant may exist in its long form $\left(\mathrm{cFLIP}_{\mathrm{L}}\right)$, and short $\left(\mathrm{cFLIP}_{\mathrm{s}}\right)$ form. Because of cFLIP's very high sequence homology to caspase-8, it competes with caspase-8 for binding to FADD within DISC and thereby prevents the binding of caspase- 8 to FADD. This interaction of cFLIP with FADD prevents the receptor mediated apoptosis. Elevated expression of cFLIP has been observed in several kinds of tumours. For example, cFLIP is overexpressed in prostrate cancer, cervical cancer, ovarian cancer, colorectal cancer, gastric cancer, pancreatic cancer, and B cell chronic lymphocytic leukaemia. ${ }^{157}$ There are many reports indicating that downregulation of cFLIP sensitises tumour cells to apoptosis. For example, a recent finding has shown that cFLIP is a key regulator in colorectal cancer. siRNA mediated inhibition of cFLIP, induced apoptosis in p53 wild type, mutant and null colorectal cancer cells. ${ }^{158}$ Apart from that, intra-tumour delivery of siRNA duplexes induced apoptosis in xenografts of SCID mice. These experimental findings provide evidence that targeting of cFLIP in colorectal cancers can provide a potential therapeutic target.

Beside antisense oligonucleotides that target cFLIP, several small molecule inhibitors have the potential to downregulate the expression of cFLIPs, like DNA targeting anticancer drugs cisplatin and doxorubicin. ${ }^{157}$ Additionally, there are RNA synthesis and histone deacetylase inhibitors which can potentially downregulate cFLIP expression. ${ }^{157}$ Recently, it has been shown that administration of methyl-2-cyano-3, 12-dioxooleana-1, 9-dien-28-oate (CDDO-Me), a novel synthetic triterpenoid to human lung cancer cells, triggers induction of apoptosis by targeting cFLIPs to ubiquitination dependent, proteosomal degradation. ${ }^{159}$ siRNA mediated knock down of cFLIP potentiated the anti-cancer effect of CDDO-Me. CDDOMe entered phase 1 clinical trial with a very promising results. ${ }^{159}$

\section{Inhibitor of apoptosis proteins in cancer therapy}

The inhibitor of apoptosis proteins (IAPs) were originally discovered in baculovirus as suppressors of host cell apoptosis ${ }^{160}$; however, they can be found in both invertebrates and vertebrates. Thus far, eight human IAPs family members have been identified including neuronal apoptosis inhibitory protein or (NAIP) (also known as BIRC1 or baculoviral IAP repeatcontaining 1), cellular IAP 1 or cIAP1 (also known as HIAP2, MIHB, and BIRC2), cIAP2 (also known as HIAP1, MIHC, and BIRC3), X-chromosome linked IAP or XIAP (also known as hILP, MIHA, and BIRC4), survivin (also known as TIAP and BIRC5), Apollon (also known as Bruce and BIRC6), melanoma IAP or ML-IAP (also known as KIAP, livin, and BIRC7), and IAPlike protein 2 (also known as BIRC8), which are reviewed elsewhere. ${ }^{161}$

All IAP proteins share two to three common structures of baculovirus IAP repeat (BIR) domains to bind and inactivate caspases, except survivin, the smallest human IAP protein which contains only a single BIR repeat. ${ }^{161}$ Most of the IAP proteins, excluding survivin, possess a carboxyl-terminal RING domain containing ubiquitin ligases required for ubiquitination and proteasomal degradation of caspases. ${ }^{161}$ XIAP is the most efficient caspase inhibitor among the IAP family members. ${ }^{162}$ Inhibition of apoptosis by XIAP is mainly coordinated through binding to initiator caspase- 9 and effector caspases-3 and $-7 .{ }^{163}$
Elevated expression of IAPs in several human malignancies has been reported. Tamm et al ${ }^{164}$ investigated expression of IAPs in 60 human tumour cell lines at mRNA and protein levels and found higher expression of XIAP and cIAP1 in most cancer cell lines analysed. Elevated expression of IAP family members in malignant cells can be influenced by different intra- and/or extracellular factors such as TNF. Survivin, an atypical IAP, is highly expressed in rapidly dividing cells and many cancers. ${ }^{165} 166$ Espinosa and colleagues ${ }^{167}$ investigated the expression of several IAPs including c-IAP1, cIAP2, XIAP and survivin in cervical cancer. Although their finding indicates no differences in the expression of cIAP2 and XIAP between normal vs cancer samples, higher expression of survivin isoforms, $2 \mathrm{~B}$ and DeltaEx3, along with downregulation of cIAP1 were detected in the cervical cancer samples. Nuclear expression of survivin in cancer cells has also been reported by Giodini and colleagues, ${ }^{168}$ demonstrating its role in cell division via controlling of microtubule stability and assembly of a normal mitotic spindle. Authors also hypothesised that nuclear localisation of survivin in cancer cells may facilitate checkpoint evasion and promote resistance to drugs targeting mitotic spindles. ${ }^{168}$

Attempts have been made to therapeutically target IAP proteins by small molecules or by antisense approaches. ${ }^{169}$ For example, OSU-03012 is a potent experimental anticancer drug, a derivative of celecoxib, known for its activity on multiple myeloma cells. ${ }^{170}$ One of its proposed mechanisms of action is downregulation of the expression of inhibitor for caspases such as survivin and XIAP, followed by cell cycle arrest and induction of apoptosis.

Triptolide, a diterpenoid isolated from a Chinese herb, induces a broad range of anticancer activities on solid tumours. ${ }^{171}$ For example, triptolide induced caspase dependent apoptosis by downregulating XIAP, and enhancing mitochondrial death pathway by activating caspase-9. A recent report published by Carter and colleagues demonstrates that triptolide can also enhance TRAIL induced apoptosis in acute myeloid leukaemia (AML) cells by downregulating the expression of XIAP and elevating the levels of DR5, a receptor for TRAIL. ${ }^{172}$

cIAP1 protein level could be downregulated by a small molecule inhibitor, (-)-N- [(2S, 3R)-3-amino-2-hydroxy-4-phenyl-butyryl]-l-leucine methyl ester (ME-BS), that induces its auto-ubiqitilation. ${ }^{173} \mathrm{ME}-\mathrm{BS}$ directly interacts with BIR3 domain of cIAP1 and promotes its proteosomal degradation.

Another approach enhancing apoptosis is based on overexpression of Smac/DIABLO, an IAP-inhibitor, and subsequent treatment with anticancer drugs such as doxorubicin, etoposide, paclitaxel and tamoxifen. Such combined treatment increased the total number of apoptotic breast cancer cells as compared with using the respective anticancer drugs alone. ${ }^{174} \mathrm{Smac} /$ DIABLO overexpression also sensitised breast cancer cells to TRAIL. Several attempts have been made to develop cell permeable N-terminal peptides derived from the Smac that would serve itself as IAP inhibitors. ${ }^{175}{ }^{176}$ Co-administration of these Smac peptides with etoposide, doxorubicin, and TRAIL resulted in alleviation of IAP effects as well as an increased apoptotic response. This was observed in several tumour cell lines, including breast, neuroblastoma, melanoma, and NSCLC as well as in a malignant glioma xenograft model in vivo. ${ }^{176} 177$ Like other peptides, Smac peptides might be difficult to use in clinical settings due to stability issues, immunogenicity and poor tissue distribution. Thus, the next generation of such drugs will likely be based on peptidomimetics.

AEG35156 is a 19-mer oligonucleotide that is being developed by Aegera therapeutics (Montreal, Canada). AEG35156 effi- 
ciently reduced the mRNA level of XIAP and sensitised cancer cells to apoptotic cell death. It also exhibited potent antitumour activity in the human cancer xenograft models. ${ }^{178}$ Presently, the drug is in phase 1 clinical trial in cancer patients as a single agent as well as in combination with docetaxel. ${ }^{178}$

$N$-[(5R)-6-[(anilinocarbonyl) amino]-5-((anilinocarbonyl), amino) hexyl]-N-methyl-N'-phenylurea (1396-12), one of the antagonists of XIAP, a small molecule inhibitor and a member of polyphenyl urea, efficiently induced apoptosis in AML cells and in the primary patient samples by downregulating expression of XIAP. ${ }^{179}$ However it did not have any cytotoxic effects on the normal haematopoietic cells, indicating its specificity in killing cancer cells. ${ }^{179}$ Other XIAP small molecule antagonists, such as 1396-11 and 1396-28, have been developed. ${ }^{180}$ In vitro studies using these compounds in pancreatic cancer cell lines and also in xenograft models showed that they can impede neoplastic growth by inhibiting XIAP. These compounds also showed synergy when applied in combination with TRAIL, gemcitabine, and radiation. ${ }^{180}$

Survivin has been recently singled out among the factors responsible for the resistance of colorectal cancer to standard therapies. ${ }^{181}$ Using siRNA technology, it has been demonstrated that inhibition of survivin potentiated the cancer cell death upon irradiation. ${ }^{181}$ Interaction of survivin with hsp90 (heat shock protein 90) is well documented and this interaction is vital for the stability of surviving. ${ }^{182}$ A cell permeable peptidomimetic, shephedrin, is based on the binding interface of survivin and Hsp90. ${ }^{183}$ Shephedrin destabilises the above interaction, thus depleting survivin, and selectively induces apoptosis only in tumour cells but not in normal cells, by both caspase dependent and independent mechanisms. ${ }^{183}$ shRNA mediated inhibition of survivin expression combined with the introduction of apoptin, a viral protein that selectively kills cancer cells, has recently been tested, and the data reveal synergistic effects of both treatments. ${ }^{184} 185$ Apart from the above approaches, anti-survivin hammerhead ribozymes have been developed that can effectively downregulate survivin's expression, and hence potentiate cancer cell apoptosis. ${ }^{186-188}$

\section{Direct activation of caspases by pharmacologic agents}

Numerous approaches to trigger direct caspase activation specifically in tumour cells have been tested. This tactic appears to be very promising since some caspases, most prominently procaspase-3, are maintained in an inactive conformation by an Asp-Asp-Asp "safety-catch", a regulatory tripeptide located within a flexible loop near the large subunit/small subunit junction. When these interactions are disturbed by mutation or by simple $\mathrm{pH}$ lowering, a substantial proportion of procaspase-3 molecules undergo spontaneous auto-activation.

Following this approach, Jiang and colleagues identified a small molecule drug, $\alpha$-(trichloromethyl)-4-pyridineethanol (PETCM), that could activate procaspase-3 in cell extracts. ${ }^{189}$ However, this compound is an unlikely therapeutic agent, as high concentrations $(200 \mu \mathrm{M})$ are required to activate caspase- 3 in vitro. A series of small molecule caspase-activating drugs (MX-2060), derivatives of gambogic acid, were also evaluated for direct caspase-3 activation. ${ }^{190}$ Gambogic acid's relatively low half maximal effective concentration $\left(E_{50}\right.$ ) of $0.78 \mu \mathrm{M}$ in a caspase activation assay in T47D breast cancer cells makes it a more attractive candidate for a caspase activating drug. Its derivative, MX-2167, has been shown to induce apoptosis in prostate, breast, colorectal and lung cancer cell lines, and to suppress tumour growth up to $90 \%$ in a syngeneic prostate animal cancer model.
Most recently, a small molecule, PAC-1, has been identified that directly activates procaspase- 3 in vitro $\left(\mathrm{EC}_{50}\right.$ for activation of $0.22 \mu \mathrm{M}$ on procaspase-3) and induces apoptosis in tumour cells isolated from primary colon cancer in a manner directly proportional to the concentration of procaspase- 3 inside these cells. ${ }^{191}$ This compound prevented tumour growth in three different murine models of cancer, including two models in which PAC-1 was administered orally. ${ }^{191}$ In fact, a systematic evaluation of procaspase- 3 concentrations in the panel of 60 cell lines used by the National Cancer Institute revealed that particular lung, melanoma, renal and breast cancers show greatly enhanced concentrations of procaspase- $3 .{ }^{192}$ Therefore, targeting caspase- 3 activation could be a valuable strategy for cancer therapy.

PAC-1 induces apoptosis in a variety of cancer cell lines. In HL-60 cells, the addition of PAC-1 induced the appearance of many apoptotic hallmarks. ${ }^{191}$ PAC-1 treatment cause considerable phosphatidylserine externalisation as assessed by annexin $\mathrm{V}$ staining, a hallmark of apoptosis. This effect was observed at PAC-1 concentrations between 5-100 $\mu \mathrm{M}$. PAC-1 also induced chromatin condensation in HL-60 cells, as visualised by Hoechst-33258 staining. ${ }^{191}$ Furthermore, PAC-1 mediated caspase- 3 activation was confirmed by detection of cleaved caspase substrate poly-ADP-ribose polymerase 1 (PARP-1), and observed mitochondrial membrane depolarisation. ${ }^{191}$ Perhaps most interestingly, PAC-1 shows some selective toxicity towards cancer cells. When tested on matched normal epithelial and colon adenocarcinoma cells obtained from the same donors, the $\mathrm{IC}_{50}$ values for cancer cells were between $0.003-1.41 \mu \mathrm{M}$, whereas for normal cells the $\mathrm{IC}_{50}$ values were $5.02-9.98 \mu \mathrm{M}$. The increased susceptibility of colon cancer cells to PAC-1 correlated well with 1.7-19.7-fold (average of 8.4-fold) increased expression of procaspase-3 in cancer cells as compared to their normal counterparts. $^{191}$

\section{EPILOGUE}

The apoptotic potential of cancer cells in correlation to their proliferative dynamics profoundly affects malignant phenotypes, and it appears that pathways governing cell proliferation and cell death are interconnected. ${ }^{193} 194$ Failure to enter apoptosis allows transformed cells to enter further cell divisions and acquire further mutations. In the present review, we focus on genetic alterations of caspases and their regulators, underlining the role of these molecules in cancer development. Deregulation of caspase expression and/or activity could be a result of various factors, including genetic alterations, promoter methylation, alternative splicing and posttranslational modifications. ${ }^{139}$ 195-197 We show examples that different mutation could have profound effects on caspases activity.

The majority of currently available anticancer drugs act at least in part through induction of apoptosis ${ }^{198-200}$; therefore, a defect in the apoptotic propensity of tumours affects their response to treatment. Some experimental treatments-for example, apoptin - seem to "hijack" cell's proliferation promoting pathways, and redirect them to induce apoptosis. ${ }^{201} 202$ Beside traditional radio- and chemotherapies, new treatment methods are being developed that utilise natural products such as Brevinin-2R, and immunomodulators such as S100A8/A9, and even utilisation of stem cells. ${ }^{20} 24203204$ As described above, a number of anticancer therapies are being tested that influence the expression and/or activity of factors that regulate apoptosis. Targeting caspases and apoptotic machinery will play an increasingly important role in future modern cancer therapy, and approaches are being developed that allow "on demand" 
activation of expression. ${ }^{205}$ This will be achieved using siRNA technology, the small molecule inhibitors, as well as peptides and peptidomimetics. These approaches may eventually replace the traditional chemo- and radiation therapies, and result in more efficient cancer treatments that are devoid of side effects.

Acknowledgements: ML acknowledges the support from DFG (SFB 773, GRK 1302) and the Deutsche Krebshilfe. We also acknowledge and apologise to all those authors whose work was not directly referenced here due to space limitations.

Funding: SG is supported by a CIHR/Canadian Lung Association/GSK Fellowship, Manitoba Institute of child Health (MICH), and by the National Training Program in Allergy and Asthma (NTPAA). AJH holds a Canada Research Chair; ME is supported by a MICH studentship, and BY is supported by CIHR, Manitoba Health Research Council (MHRC), and Institute of Cardiovascular Sciences (ICS) studentship.

Competing interests: None declared

\section{REFERENCES}

1. Kops GJ, Weaver BA, Cleveland DW. On the road to cancer: aneuploidy and the mitotic checkpoint. Nat Rev Cancer 2005:5:773-85.

2. Hombach-Klonisch S, Paranjothy T, Wiechec E, Pocar P, Mustafa T, Seifert A, Zahl C, Gerlach KL, Biermann K, Steger K, Hoang-Vu C, Schulze-Osthoff K, Los M. Cancer stem cells as targets for cancer therapy: selected cancers as examples. Arch Immunol Ther Exp 2008;56:165-80.

3. Klonisch T, Wiechec E, Hombach-Klonisch S, Ande SR, Wesselborg S, SchulzeOsthoff K, Los M. Cancer stem cell markers in common cancers - therapeutic implications. Trends Mol Med 2008;14:450-60.

4. Jiang G, Yang F, Li M, Weissbecker K, Price S, Kim KC, La Russa VF, Safah H, Ehrlich M. Imatinib (ST1571) provides only limited selectivity for CML cells and treatment might be complicated by silent BCR-ABL genes. Cancer Biol Ther 2003;2:103-8.

5. Jin S, DiPaola RS, Mathew R, White E. Metabolic catastrophe as a means to cancer cell death. J Cell Sci 2007;120:379-83.

6. Brown GD. Sensing necrosis with Mincle. Nat Immunol 2008;9:1099-100.

7. Lauber K, Blumenthal SG, Waibel M, Wesselborg S. Clearance of apoptotic cells: getting rid of the corpses. Mol Cell 2004:14:277-87.

8. Ozben T. Oxidative stress and apoptosis: impact on cancer therapy. J Pharm Sci 2007:96:2181-96.

9. Salvesen GS, Dixit VM. Caspases: intracellular signaling by proteolysis. Cell 1997:91:443-6.

10. Thornberry NA, Lazebnik Y. Caspases: enemies within. Science 1998;281:1312-6.

11. Adams JM. Ways of dying: multiple pathways to apoptosis. Genes Dev 2003:17:2481-95.

12. Kischkel FC, Hellbardt S, Behrmann I, Germer M, Pawlita M, Krammer PH, Peter ME. Cytotoxicity-dependent APO-1 (Fas/CD95)-associatedproteins from a deathinducing signaling complex (DISC) with the receptor. EMBO J 1995;14:5579-88.

13. Ashkenazi A, Dixit VM. Death receptors: signaling and modulation. Science 1998;281:1305-8.

14. Boldin MP, Varfolomeev EE, Pancer Z, Mett IL, Camonis JH, Wallach D. A novel protein that interacts with the death domain of Fas/APO-1 contains a sequence motif related to the death domain. J Biol Chem 1995;270:7795-8.

15. Bodmer JL, Holler N, Reynard S, Vinciguerra P, Schneider P, Juo P, Blenis J, Tschopp J. TRAIL receptor-2 signals apoptosis through FADD and caspase-8. Nat Cell Biol 2000;2:241-3.

16. Los M, Panigrahi S, Rashedi I, Mandal S, Stetefeld J, Essmann F, Schulze-Osthoff K. Apoptin, a tumor-selective killer. Biochim Biophys Acta (in press, PMID: 19374922)

17. Sprick MR, Weigand MA, Rieser E, Rauch CT, Juo P, Blenis J, Krammer PH, Walczak H. FADD/MORT1 and caspase-8 are recruited to TRAll receptors 1 and 2 and are essential for apoptosis mediated by TRAIL receptor. Immunity 2000;12:599-609.

18. Kuang AA, Diehl G, Zhang J, Winoto A. FADD is required for DR4- and DR5mediated apoptosis: Lack of TRAllinduced apoptosis in FADD-deficient mouse embryonic fibroblasts. J Biol Chem 2000;275:25065-8.

19. Li J, Yuan J. Caspases in apoptosis and beyond. Oncogene 2008;27:6194-206.

20. Ghavami S, Asoodeh A, Klonisch T, Halayko AJ, Kadkhoda K, Kroczak TJ, Gibson SB, Booy EP, Naderi-Manesh H, Los M. Brevinin-2R(1) semi-selectively kills cancer cells by a distinct mechanism, which involves the lysosomal-mitochondrial death pathway. J Cell Mol Med 2008;12:1005-22.

21. Ghavami S, Kerkhoff C, Los M, Hashemi M, Sorg C, Karami-Tehrani F. Mechanism of apoptosis induced by S100A8/A9 in colon cancer cell lines: the role of ROS and the effect of metal ions. J Leukoc Biol 2004;76:169-75.

22. Hashemi M, Karami Tehrani F, Ghavami S. Cytotoxicity effect of Cladribine on the MCF-7 human breast cancer cell line. Iranian Biomed J 2004:8:7-12.

23. Kim R. Recent advances in understanding the cell death pathways activated by anticancer therapy. Cancer 2005:103:1551-60.

24. Ghavami S, Kerkhoff C, Chazin WJ, Kadkhoda K, Xiao W, Zuse A, Hashemi M, Eshraghi M, Schulze-Osthoff K, Klonisch T, Los M. S100A8/9 induces cell death via a novel, RAGE-independent pathway that involves selective release of Smac/DIABLO and Omi/HtrA2. Biochim Biophys Acta 2008;1783:297-311.

25. Ghobrial IM, Witzig TE, Adjei AA. Targeting apoptosis pathways in cancer therapy. CA Cancer J Clin 2005:55:178-94.
26. Ly JD, Grubb DR, Lawen A. The mitochondrial membrane potential (deltapsi(m)) in apoptosis; an update. Apoptosis 2003;8:115-28.

27. Bratton SB, MacFarlane M, Cain K, Cohen GM. Protein complexes activate distinct caspase cascades in death receptor and stress-induced apoptosis. Exp Cell Res 2000;256:27-33

28. Adrain C, Martin SJ. The mitochondrial apoptosome: a killer unleashed by the cytochrome seas. Trends Biochem Sci 2001;26:390-7.

29. Chinnaiyan AM. The apoptosome: heart and soul of the cell death machine. Neoplasia 1999:1:5-15.

30. Riedl SJ, Shi Y. Molecular mechanisms of caspase regulation during apoptosis. Nat Rev Mol Cell Biol 2004;5:897-907.

31. Philchenkov A, Zavelevich M, Kroczak TJ, Los M. Caspases and cancer: mechanism of inactivation and new treatment modalities. Exp Oncol 2004;26:82-97.

32. Li P, Nijhawan D, Budihardjo I, Srinivasula SM, Ahmad M, Alnemri ES, Wang X. Cytochrome $c$ and dATP-dependent formation of Apaf-1/caspase- 9 complex initiates an apoptotic protease cascade. Cell 1997;91:479-89.

33. Lorenzo HK, Susin SA, Penninger J, Kroemer G. Apoptosis inducing factor (AIF): a phylogenetically old, caspase independent effector of cell death. Cell Death Differ 1999;6:516-424.

34. Du C, Fang M, Li Y, Li L, Wang X. Smac, a mitochodrial protein that promotes cytochrome c-dependent caspase activation by eliminating IAP inhibition. Cell 2000; 102:33-42

35. Li W, Srinivasula SM, Chai J, Li P, Wu JW, Zhang Z, Alnemri ES, Shi Y. Structural insights into the pro- apoptotic function of mitochondrial serine protease HrtA2/Omi. Nat Strut Biol 2002;9:436-41.

36. Van Loo G, Saelens X, Van Group M, MacFarlane M, Martin SJ, Vandenabeele P. The role of mitochondrial factors in apoptosis: a Russian roulette with more than one bullet. Cell Death Differ 2002;9:1031-42.

37. Debatin KM. Apoptosis pathways in cancer and cancer therapy. Cancer Immunol Immunother 2004;53:153-9.

38. Los M, van de Craen M, Penning CL, Schenk H, Westendorp M, Baeuerle PA, Dröge W, Krammer PH, Fiers W, Schulze-Osthoff K. Requirement of an ICE/Ced-3 protease for Fas/Apo-1-1mediated apoptosis. Nature 1995;375:81-3.

39. Yuan J, Shaham S, Ledoux S, Ellis HM, Horvitz HR. The C. elegans cell death gene ced-3 encodes a protein similar to mammalian interleukin-1 beta-converting enzyme. Cell 1993; 75:641-52

40. Los M, Wesselborg S, Schulze-Osthoff K. The role of caspases in development, immunity, and apoptotic signal transduction: lessons from knockout mice. Immunity 1999;10:629-39.

41. Pistritto G, Jost M, Srinivasula SM, Baffa R, Poyet JL, Kari C, Lazebnik Y, Rodeck U, Alnemri ES. Expression and transcriptional regulation of caspase-14 in simple and complex epithelia. Cell Death Differ 2002;9:995-1006.

42. Koenig U, Eckhart L, Tschachler E. Evidence that caspase-13 is not a human but a bovine gene. Biochem Biophys Res Commun 2001;285:1150-4.

43. Degterev A, Boyce M, Yuan J. A decade of caspases. Oncogene 2003;22:8543-67.

44. Kang TB, Ben-Moshe T, Varfolomeev EE, Pewzner-Jung Y, Yogev N, Jurewicz A Waisman A, Brenner O, Haffner R, Gustafsson E, Ramakrishnan P, Lapidot T, Wallach D. Caspase-8 serves both apoptotic and nonapoptotic roles. J Immunol 2004:173:2976-84.

45. Los M, Stroh C, Janicke RU, Schulze-Osthoff K. Caspases: more than just killers? Trends Immunol 2001;22:31-4.

46. Martinon F, Tschopp J. Inflammatory caspases: linking an intracellular innate immune system to autoinflammatory diseases. Cell 2004;117:561-74.

47. Salvesen GS, Riedl SJ. Caspase mechanisms. Adv Exp Med Biol 2008;615:13-23.

48. Wolf BB, Green DR. Suicidal tendencies: apoptotic cell death by caspase family proteinases. J Biol Chem 1999;274:20049-52.

49. Wang ZB, Liu YQ, Cui YF. Pathways to caspase activation. Cell Biol Int 2005;29:489-96.

50. Stergiou L, Hengartner MO. Death and more: DNA damage response pathways in the nematode C. elegans. Cell Death Differ 2004;11:21-8.

51. Read SH, Baliga BC, Ekert PG, Vaux DL, Kumar S. A novel Apaf-1-independent putative caspase-2 activation complex. J Cell Biol 2002;159:739-45.

52. Tinel A, Tschopp J. The PIDDosome, a protein complex implicated in activation of caspase-2 in response to genotoxic stress. Science 2004;304:843-6.

53. Harvey NL, Butt AJ, Kumar S. Functional activation of Nedd2/ICH-1 (caspase-2) is an early process in apoptosis. J Biol Chem 1997;272:13134-9.

54. Ahmad M, Srinivasula SM, Wang L, Talanian RV, Litwack G, Fernandes-Alnemri T, Alnemri ES. CRADD, a novel human apoptotic adaptor molecule for caspase-2, and FasL/tumor necrosis factor receptor-interacting protein RIP. Cancer Res 1997:57:615-9.

55. O'Reilly LA, Ekert P, Harvey N, Marsden V, Cullen L, Vaux DL, Hacker G, Magnusson C, Pakusch M, Cecconi F, Kuida K, Strasser A, Huang DC, Kumar S. Caspase-2 is not required for thymocyte or neuronal apoptosis even though cleavage of caspase-2 is dependent on both Apaf-1 and caspase-9. Cell Death Differ 2002; $9: 832-41$

56. Mancini M, Machamer CE, Roy S, Nicholson DW, Thornberry NA, Casciola-Rosen $L A$, Rosen A. Caspase-2 is localized at the Golgi complex and cleaves golgin-160 during apoptosis. J Cell Biol 2000;149:603-12.

57. Baliga BC, Colussi PA, Read SH, Dias MM, Jans DA, Kumar S. Role of prodomain in importin-mediated nuclear localization and activation of caspase-2. J Biol Chem 2003:278:4899-905 
58. Bonzon C, Bouchier-Hayes L, Pagliari LJ, Green DR, Newmeyer DD. Caspase-2induced apoptosis requires bid cleavage: a physiological role for bid in heat shockinduced death. Mol Biol Cell 2006;17:2150-7.

59. Guo Y, Srinivasula SM, Druilhe A, Fernandes-Alnemri T, Alnemri ES. Caspase-2 induces apoptosis by releasing proapoptotic proteins from mitochondria. J Biol Chem 2002;277:13430-7.

60. Robertson JD, Gogvadze V, Kropotov A, Vakifahmetoglu H, Zhivotovsky B, Orrenius $\mathrm{S}$. Processed caspase-2 can induce mitochondria-mediated apoptosis independently of its enzymatic activity. EMBO Rep 2004:5:643-8.

61. Cuenin S, Tinel A, Janssens S, Tschopp J. p53-induced protein with a death domain (PIDD) isoforms differentially activate nuclear factor-kappaB and caspase-2 in response to genotoxic stress. Oncogene 2008;27:387-96.

62. Zhang Y, Padalecki SS, Chaudhuri AR, De Waal E, Goins BA, Grubbs B, Ikeno Y, Richardson A, Mundy GR, Herman B. Caspase-2 deficiency enhances aging-related traits in mice. Mech Ageing Dev 2007;128:213-21.

63. Huang P, Akagawa K, Yokoyama Y, Nohara K, Kano K, Morimoto K. T-2 toxin initially activates caspase-2 and induces apoptosis in U937 cells. Toxicol Lett 2007:170:1-10.

64. Ghavami S, Eshraghi M, Kadkhoda K, Mutawe MM, Maddika S, Bay GH, Wesselborg S. Halayko AJ, Klonisch T, Los M. Role of BNIP3 in TNF-induced cell death - TNF upregulates BNIP3 expression. Biochim Biophys Acta 2009;1793:546-60.

65. Carrington PE, Sandu C, Wei Y, Hill JM, Morisawa G, Huang T, Gavathiotis E, Wei $\mathrm{Y}$, Werner $\mathrm{MH}$. The structure of FADD and its mode of interaction with procaspase8. Mol Cell 2006;22:599-610.

66. Stennicke HR, Jurgensmeier JM, Shin H, Deveraux 0 , Wolf BB, Yang X, Zhou Q, Ellerby HM, Ellerby LM, Bredesen D, Green DR, Reed JC, Froelich CJ, Salvesen GS. Pro-caspase-3 is a major physiologic target of caspase-8. J Biol Chem 1998;273:27084-90.

67. Yan N, Shi Y. Mechanisms of apoptosis through structural biology. Annu Rev Cell Dev Biol 2005:21:35-56.

68. Tschopp J, Irmler M, Thome M. Inhibition of fas death signals by FLIPs. Curr Opin Immunol 1998;10:552-8.

69. Micheau 0, Thome M, Schneider P, Holler N, Tschopp J, Nicholson DW, Briand C, Grütter MG. The long form of FLIP is an activator of caspase-8 at the Fas deathinducing signaling complex. J Biol Chem 2002;277:45162-71.

70. Chang DW, Xing Z, Pan Y, Algeciras-Schimnich A, Barnhart BC, Yaish-Ohad S, Peter ME, Yang X. c-FLIP(L) is a dual function regulator for caspase-8 activation and CD95-mediated apoptosis. EMBO J 2002:21:3704-14.

71. Irmler M, Thome M, Hahne M, Schneider P, Hofmann K, Steiner V, Bodmer JL, Schröter M, Burns K, Mattmann C, Rimoldi D, French LE, Tschopp J. Inhibition of death receptor signals by cellular FLIP. Nature 1997;388:190-5.

72. Zou H, Henzel WJ, Liu X, Lutschg A, Wang X. Apaf-1, a human protein homologous to $C$. elegans CED-4, participates in cytochrome c-dependent activation of caspase3. Cell 1997;90:405-13.

73. Rodriguez J, Lazebnik Y. Caspase-9 and APAF-1 form an active holoenzyme. Genes Dev 1999:13:3179-84.

74. Li P, Nijhawan D, Budihardjo I, Srinivasula SM, Ahmad M, Alnemri ES, Wang X. Cytochrome $\mathrm{C}$ and dATP-dependent formation of Apaf-1/caspase-9 complex initiates an apoptotic protease cascade. Cell 1997;91:479-89.

75. Oin H, Srinivasula SM, Wu G, Fernandes-Alnemri T, Alnemri ES, Shi Y. Structural basis of procaspase- 9 recruitment by the apoptotic protease-activating factor 1 . Nature 1999;399:549-57.

76. Kischkel FC, Lawrence DA, Tinel A, LeBlanc H, Virmani A, Schow P, Gazdar A Blenis J, Arnott D, Ashkenazi A. Death receptor recruitment of endogenous caspase10 and apoptosis initiation in the absence of caspase-8. J Biol Chem 2001:276:46639-46.

77. Milhas D, Cuvillier 0 , Therville N, Clavé $P$, Thomsen M, Levade T, Benoist $H$, Ségui B. Caspase-10 triggers Bid cleavage and caspase cascade activation in FasLinduced apoptosis. J Biol Chem 2005;280:19836-42.

78. Sprick MR, Rieser E, Stahl H, Grosse-Wilde A, Weigand MA, Walczak H. Caspase10 is recruited to and activated at the native TRAIL and CD95 death-inducing signalling complexes in a FADD-dependent manner but can not functionally substitute caspase-8. EMBO J 2002;21:4520-30.

79. Fischer H, Koenig U, Eckhart L, Tschachler E. Human caspase 12 has acquired deleterious mutations. Biochem Biophys Res Commun 2002;293:722-6.

80. Nakagawa T, Zhu H, Morishima N, Li E, Xu J, Yankner BA, Yuan J. Caspase-12 mediates endoplasmic-reticulum-specific apoptosis and cytotoxicity by amyloidbeta. Nature 2000:403:98-103.

81. Nakagawa T, Yuan J. Cross-talk between two cysteine protease families. Activation of caspase-12 by calpain in apoptosis. J Cell Biol 2000;150:887-94.

82. Fan TJ, Han LH, Cong RS, Liang J. Caspase family proteases and apoptosis. Acta Biochim Biophys Sin (Shanghai) 2005;37:719-27

83. Morishima N, Nakanishi K, Takenouchi H, Shibata T, Yasuhiko Y. An endoplasmic reticulum stress-specific caspase cascade in apoptosis. Cytochrome c-independent activation of caspase-9 by caspase-12. J Biol Chem 2002;277:34287-94.

84. Rao RV, Hermel E, Castro-Obregon S, del Rio G, Ellerby LM, Ellerby HM, Bredesen DE. Coupling endoplasmic reticulum stress to the cell death program. Mechanism of caspase activation. J Biol Chem 2001;276:33869-74

85. Hitomi J, Katayama T, Eguchi Y, Kudo T, Taniguchi M, Koyama Y, Manabe T, Yamagishi S, Bando Y, Imaizumi K, Tsujimoto Y, Tohyama M. Involvement of caspase-4 in endoplasmic reticulum stress-induced apoptosis and Abeta-induced cell death. J Cell Biol 2004:165:347-56.
86. Hauff K, Zamzow C, Law WJ, De Melo J, Kennedy K, Los M. Peptide-based approaches to treat asthma, arthritis, other autoimmune diseases and pathologies of the central nervous system. Arch Immunol Ther Exp 2005;53:308-20.

87. Smith DJ, McGuire MJ, Tocci MJ, Thiele DL. IL-1 beta convertase (ICE) does not play a requisite role in apoptosis induced in T lymphoblasts by Fas-dependent or Fasindependent CTL effector mechanisms. J Immunol 1997;158:163-70.

88. Fantuzzi G, Puren AJ, Harding MW, Livingston DJ, Dinarello CA. Interleukin-18 regulation of interferon gamma production and cell proliferation as shown in interleukin-1beta-converting enzyme (caspase-1)-deficient mice. Blood 1998;91:2118-25

89. Li $\mathbf{P}$, Allen H, Banerjee S, Seshadri T. Characterization of mice deficient in interleukin-1 beta converting enzyme. J Cell Biochem 1997:64:27-32.

90. Kang SJ, Wang S, Kuida K, Yuan J. Distinct downstream pathways of caspase-11 in regulating apoptosis and cytokine maturation during septic shock response. Cell Death Differ 2002;9:1115-25.

91. Porter AG, Janicke RU. Emerging roles of caspase-3 in apoptosis. Cell Death Differ 1999;6:99-104.

92. Slee EA, Adrain C, Martin SJ. Executioner caspase-3, -6, and -7 perform distinct non-redundant roles during the demolition phase of apoptosis. J Biol Chem 2001;276:7320-6.

93. Freedman ML, Penney KL, Stram DO, Le Marchand L, Hirschhorn JN, Kolonel LN, Altshuler D, Henderson BE, Haiman CA. Common variation in BRCA2 and breast cancer risk: a haplotype-based analysis in the Multiethnic Cohort. Hum Mol Genet 2004; 13:2431-41.

94. Soung YH, Lee JW, Kim SY, Jang J, Park YG, Park WS, Nam SW, Lee JY, Yoo NJ, Lee SH. CASPASE-8 gene is inactivated by somatic mutations in gastric carcinomas. Cancer Res 2005:65:815-21.

95. Devarajan E, Sahin AA, Chen JS, Krishnamurthy RR, Aggarwal N, Brun AM, Sapino A, Zhang F, Sharma D, Yang XH, Tora AD, Mehta K. Down-regulation of caspase 3 in breast cancer: a possible mechanism for chemoresistance. Oncogene 2002;21:8843-51

96. Hopkins-Donaldson S, Ziegler A, Kurtz S, Bigosch C, Kandioler D, Ludwig C, Zangemeister-Wittke U, Stahel R. Silencing of death receptor and caspase-8 expression in small cell lung carcinoma cell lines and tumors by DNA methylation. Cell Death Differ 2003:10:356-64.

97. Cox A, Dunning AM, Garcia-Closas M, Balasubramanian S, Reed MW, Pooley KA Scollen S, Baynes C, Ponder BA, Chanock S, Lissowska J, Brinton L, Peplonska B Southey MC, Hopper JL, McCredie MR, Giles GG, Fletcher O, Johnson N, dos Santos Silva I, Gibson L, Bojesen SE, Nordestgaard BG, Axelsson CK, Torres D, Hamann U, Justenhoven C, Brauch H, Chang-Claude J, Kropp S, Risch A, WangGohrke S, Schürmann P, Bogdanova N, Dörk T, Fagerholm R, Aaltonen K, Blomqvist C, Nevanlinna H, Seal S, Renwick A, Stratton MR, Rahman N, Sangrajrang S, Hughes D, Odefrey F, Brennan P, Spurdle AB, Chenevix-Trench G, Kathleen Cunningham Foundation Consortium for Research into Familial Breast Cancer, Beesley J, Mannermaa A, Hartikainen J, Kataja V, Kosma VM, Couch FJ, Olson JE, Goode EL, Broeks A, Schmidt MK, Hogervorst FB, Van't Veer LJ, Kang D, Yoo KY, Noh DY, Ahn SH, Wedrén S, Hall P, Low YL, Liu J, Milne RL, Ribas G, Gonzalez-Neira A, Benitez J, Sigurdson AJ, Stredrick DL, Alexander BH, Struewing JP, Pharoah PD, Easton DF, Breast Cancer Association Consortium. A common coding variant in CASP8 is associated with breast cancer risk. Nat Genet 2007:39:352-8.

98. Haiman CA, Garcia RR, Kolonel LN, Henderson BE, Wu AH, Le Marchand L. A promoter polymorphism in the CASP8 gene is not associated with cancer risk. Nat Genet 2008:40:259-60; author reply 60-1.

99. Kolonel LN, Henderson BE, Hankin JH, Nomura AM, Wilkens LR, Pike MC, Stram DO, Monroe KR, Earle ME, Nagamine FS. A multiethnic cohort in Hawaii and Los Angeles: baseline characteristics. Am J Epidemiol 2000;151:346-57.

100. Bethke L, Sullivan K, Webb E, Murray A, Schoemaker M, Auvinen A, Kiuru A, Salminen T, Johansen C, Christensen HC, Muir K, McKinney P, Hepworth S, Dimitropoulou P, Lophatananon A, Feychting M, Lönn S, Ahlbom A, Malmer B, Henriksson R, Swerdlow A, Houlston R. CASP8 D302H and meningioma risk: An analysis of five case-control series. Cancer Lett 2009:273:312-5.

101. Cardis E, Richardson L, Deltour I, Armstrong B, Feychting M, Johansen C, Kilkenny M, McKinney P, Modan B, Sadetzki S, Schüz J, Swerdlow A, Vrijheid M, Auvinen A Berg G, Blettner M, Bowman J, Brown J, Chetrit A, Christensen HC, Cook A, Hepworth S, Giles G, Hours M, lavarone I, Jarus-Hakak A, Klaeboe L, Krewski D, Lagorio S, Lönn S, Mann S, McBride M, Muir K, Nadon L, Parent ME, Pearce N, Salminen T, Schoemaker M, Schlehofer B, Siemiatycki J, Taki M, Takebayashi T, Tynes T, van Tongeren M, Vecchia P, Wiart J, Woodward A, Yamaguchi N. The INTERPHONE study: design, epidemiological methods, and description of the study population. Eur J Epidemiol 2007;22:647-64.

102. Rajaraman P, Wang SS, Rothman N, Brown MM, Black PM, Fine HA, Loeffler JS Selker RG, Shapiro WR, Chanock SJ, Inskip PD. Polymorphisms in apoptosis and cell cycle control genes and risk of brain tumors in adults. Cancer Epidemiol Biomarkers Prev 2007:16:1655-61.

103. Yang M, Sun T, Wang L, Yu D, Zhang X, Miao X, Liu J, Zhao D, Li H, Tan W, Lin D. Functional variants in cell death pathway genes and risk of pancreatic cancer. Clin Cancer Res 2008:14:3230-6.

104. Schwartzbaum JA, Fisher JL, Aldape KD, Wrensch M. Epidemiology and molecular pathology of glioma. Nat Clin Pract Neurol 2006;2:494-503; quiz 1 p following 16 .

105. Martinez R, Setien F, Voelter C, Casado S, Quesada MP, Schackert G, Esteller M $\mathrm{CpG}$ island promoter hypermethylation of the pro-apoptotic gene caspase- 8 is a 
common hallmark of relapsed glioblastoma multiforme. Carcinogenesis 2007:28:1264-8.

106. Bethke L, Sullivan K, Webb E, Murray A, Schoemaker M, Auvinen A, Kiuru A Salminen T, Johansen C, Christensen HC, Muir K, McKinney P, Hepworth S, Dimitropoulou P, Lophatananon A, Feychting M, Lönn S, Ahlbom A, Malmer B Henriksson R, Swerdlow A, Houlston R. The common D302H variant of CASP8 is associated with risk of glioma. Cancer Epidemiol Biomarkers Prev 2008;17:987-9.

107. Sun T, Gao Y, Tan W, Ma S, Shi Y, Yao J, Guo Y, Yang M, Zhang X, Zhang Q, Zeng $\mathrm{C}$, Lin D. A six-nucleotide insertion-deletion polymorphism in the CASP8 promoter is associated with susceptibility to multiple cancers. Nat Genet 2007:39:605-13.

108. Frank B, Rigas SH, Bermejo JL, Wiestler M, Wagner K, Hemminki K, Reed MW, Sutter C, Wappenschmidt B, Balasubramanian SP, Meindl A, Kiechle M, Bugert P, Schmutzler RK, Bartram CR, Justenhoven C, Ko YD, Bruning T, Brauch H, Hamann U, Pharoah PP, Dunning AM, Pooley KA, Easton DF, Cox A, Burwinkel B. The CASP8 652 6N del promoter polymorphism and breast cancer risk: a multicenter study. Breast Cancer Res Treat 2008;111:139-44.

109. MacPherson G, Healey CS, Teare MD, MacPherson G, Healey CS, Teare MD, Balasubramanian SP, Reed MW, Pharoah PD, Ponder BA, Meuth M, Bhattacharyya NP, Cox A. Association of a common variant of the CASP8 gene with reduced risk of breast cancer. J Natl Cancer Inst 2004:96:1866-9.

110. Rafii S, O'Regan P, Xinarianos G, Azmy I, Stephenson T, Reed M, Meuth M, Thacker J, Cox A. A potential role for the XRCC2 R188H polymorphic site in DNAdamage repair and breast cancer. Hum Mol Genet 2002:11:1433-8.

111. Justenhoven C, Hamann U, Schubert F, Zapatka M, Pierl CB, Rabstein S, Selinski S, Mueller T, Ickstadt K, Gilbert M, Ko YD, Baisch C, Pesch B, Harth V, Bolt HM, Vollmert C, Illig T, Eils R, Dippon J, Brauch H. Breast cancer: a candidate gene approach across the estrogen metabolic pathway. Breast Cancer Res Treat 2008; 108:137-49

112. Pesch B, Ko Y, Brauch H, Hamann U, Harth V, Rabstein S, Pierl C, Fischer HP, Baisch C, Justenhoven C, Ranft U, Bruning T. Factors modifying the association between hormone-replacement therapy and breast cancer risk. Eur J Epidemiol 2005;20:699-711

113. Baynes C, Healey CS, Pooley KA, Scollen S, Luben RN, Thompson DJ, Pharoah PD, Easton DF, Ponder BA, Dunning AM. Common variants in the ATM, BRCA1, BRCA2, CHEK2 and TP53 cancer susceptibility genes are unlikely to increase breast cancer risk. Breast Cancer Res 2007; 9:R27.

114. Jemal A, Siegel R, Ward E, Murray T, Xu J, Thun MJ. Cancer statistics, 2007. CA Cancer J Clin 2007:57:43-66.

115. Li D, Xie K, Wolff R, Abbruzzese JL. Pancreatic cancer. Lancet 2004;363:1049-57.

116. Chari ST, Leibson CL, Rabe KG, Ransom J, de Andrade M, Petersen GM. Probability of pancreatic cancer following diabetes: a population-based study. Gastroenterology 2005:129:504-11.

117. Coughlin SS, Calle EE, Teras LR, Petrelli J, Thun MJ. Diabetes mellitus as a predictor of cancer mortality in a large cohort of US adults. Am J Epidemiol 2004:159:1160-7.

118. Lu XH, Wang L, Li H, Qian JM, Deng RX, Zhou L. Establishment of risk model fo pancreatic cancer in Chinese Han population. World J Gastroenterol 2006;12:2229-34.

119. Oiu D, Kurosawa M, Lin Y, Inaba Y, Matsuba T, Kikuchi S, Yagyu K, Motohashi Y, Tamakoshi A. Overview of the epidemiology of pancreatic cancer focusing on the JACC Study. J Epidemiol 2005:15(Suppl 2):S157-67.

120. Bernstorff WV, Glickman JN, Odze RD, Farraye FA, Joo HG, Goedegebuure PS, Eberlein TJ. Fas (CD95/APO-1) and Fas ligand expression in normal pancreas and pancreatic tumors. Implications for immune privilege and immune escape. Cancer 2002; 94:2552-60.

121. Elnemr A, Ohta T, Yachie A, Kayahara M, Kitagawa H, Ninomiya I, Fushida S, Fujimura T, Nishimura G, Shimizu K, Miwa K. Human pancreatic cancer cells express non-functional Fas receptors and counterattack lymphocytes by expressing Fas ligand; a potential mechanism for immune escape. Int J Oncol 2001:18:33-9.

122. Ungefroren H, Voss M, Jansen M, Roeder C, Henne-Bruns D, Kremer B, Kalthoff H. Human pancreatic adenocarcinomas express Fas and Fas ligand yet are resistant to Fas-mediated apoptosis. Cancer Res 1998:58:1741-9.

123. Kuida K, Haydar TF, Kuan CY, Gu Y, Taya C, Karasuyama H, Su MS, Rakic P, Flavell RA. Reduced apoptosis and cytochrome c-mediated caspase activation in mice lacking caspase 9. Cell 1998;94:325-37.

124. Rashedi I, Panigrahi S, Ezzati P, Ghavami S, Los M. Autoimmunity and apoptosistherapeutic implications. Curr Med Chem 2007:14:3139-51.

125. Abel F, Sjoberg RM, Ejeskar K, Krona C, Martinsson T. Analyses of apoptotic regulators CASP9 and DFFA at 1P36.2, reveal rare allele variants in human neuroblastoma tumours. Br J Cancer 2002;86:596-604.

126. Soung YH, Lee JW, Kim SY, Park WS, Nam SW, Lee JY, Yoo NJ, Lee SH. Mutational analysis of proapoptotic caspase- 9 gene in common human carcinomas. APMIS 2006;114:292-7.

127. Park JY, Park JM, Jang JS, Choi JE, Kim KM, Cha SI, Kim CH, Kang YM, Lee WK, Kam S, Park RW, Kim IS, Lee JT, Jung TH. Caspase 9 promoter polymorphisms and risk of primary lung cancer. Hum Mol Genet 2006;15:1963-71.

128. Sun T, Miao X, Zhang X, Tan W, Xiong P, Lin D. Polymorphisms of death pathway genes FAS and FASL in esophageal squamous-cell carcinoma. J Natl Cancer Inst 2004;96:1030-6.

129. Vineis P. Molecular epidemiology: low-dose carcinogens and genetic susceptibility Int J Cancer 1997:71:1-3.

130. Hosgood HD, Baris D, Zhang Y, Zhu Y, Zheng T, Yeager M, Welch R, Zahm S, Chanock S, Rothman N, Lan O. Caspase polymorphisms and genetic susceptibility to multiple myeloma. Hematol Oncol 2008;26:148-51.
131. Juo $\mathbf{P}$, Kuo CJ, Yuan J, Blenis J. Essential requirement for caspase-8/FLICE in the initiation of the Fas-induced apoptotic cascade. Curr Biol 1998;8:1001-8.

132. Kurokawa H, Nishio K, Fukumoto H, Tomonari A, Suzuki T, Saijo N. Alteration of caspase-3 (CPP32/Yama/apopain) in wild-type MCF-7, breast cancer cells. Oncol Rep 1999;6:33-7.

133. Soung YH, Lee JW, Kim SY, Park WS, Nam SW, Lee JY, Yoo NJ, Lee SH. Somatic mutations of CASP3 gene in human cancers. Hum Genet 2004;115:112-5.

134. Chen K, Zhao H, Hu Z, Wang LE, Zhang W, Sturgis EM, Wei O. CASP3 polymorphisms and risk of squamous cell carcinoma of the head and neck. Clin Cancer Res 2008;14:6343-9.

135. Ragin CC, Modugno F, Gollin SM. The epidemiology and risk factors of head and neck cancer: a focus on human papillomavirus. J Dent Res 2007:86:104-14.

136. Kuribayashi K, Mayes PA, El-Deiry WS. What are caspases 3 and 7 doing upstream of the mitochondria? Cancer Biol Ther 2006:5:763-5.

137. Lakhani SA, Masud A, Kuida K, Porter GA Jr, Booth CJ, Mehal WZ, Inayat I, Flavell RA. Caspases 3 and 7: key mediators of mitochondrial events of apoptosis. Science 2006:311:847-51.

138. Duan H, Chinnaiyan AM, Hudson PL, Wing JP, He WW, Dixit VM. ICE-LAP3, a nove mammalian homologue of the Caenorhabditis elegans cell death protein Ced-3 is activated during Fas- and tumor necrosis factor-induced apoptosis. J Biol Chem 1996;271:1621-5

139. Soung YH, Lee JW, Kim HS, Park WS, Kim SY, Lee JH, Park JY, Cho YG, Kim CJ, Park YG, Nam SW, Jeong SW, Kim SH, Lee JY, Yoo NJ, Lee SH. Inactivating mutations of CASPASE-7 gene in human cancers. Oncogene 2003;22:8048-52.

140. Chai J, Shiozaki E, Srinivasula SM, Wu Q, Datta P, Alnemri ES, Shi Y. Structura basis of caspase-7 inhibition by XIAP. Cell 2001;104:769-80.

141. Aggarwal BB. Nuclear factor-kappaB: the enemy within. Cancer Cell 2004;6:203-8

142. Soung YH, Jeong EG, Ahn CH, Kim SS, Song SY, Yoo NJ, Lee SH. Mutational analysis of caspase 1, 4, and 5 genes in common human cancers. Hum Pathol 2008:39:895-900.

143. Los M, Herr I, Friesen C, Fulda S, Schulze-Osthoff K, Debatin KM. Cross-resistance of CD95- and drug-induced apoptosis as a consequence of deficient activation of caspases (ICE/Ced-3 proteases). Blood 1997;90:3118-29.

144. Checinska A, Giaccone G, Rodriguez JA, Kruyt FA, Jimenez CR. Comparative proteomics analysis of caspase-9-protein complexes in untreated and cytochrome c/ dATP stimulated lysates of NSCLC cells. J Proteomics 2009; 72:575-85.

145. Donoghue S, Baden HS, Lauder I, Sobolewski S, Pringle JH. Immunohistochemical localization of caspase-3 correlates with clinical outcome in B-cell diffuse large-cell lymphoma. Cancer Res 1999;59:5386-91

146. Svingen PA, Karp JE, Krajewski S, Mesner PW Jr, Gore SD, Burke PJ, Reed JC Lazebnik YA, Kaufmann SH. Evaluation of Apaf-1 and procaspases-2, -3, -7, -8, and 9 as potential prognostic markers in acute leukemia. Blood 2000;96:3922-31.

147. Li N, Zhao M, Wang J, Mesner PW Jr, Gore SD, Burke PJ, Reed JC, Lazebnik YA Kaufmann SH. Involvement of the apoptotic mechanism in pemphigus foliaceus autoimmune injury of the skin. J Immunol 2009;182:711-7.

148. Wang YL, Wang CY, Zhang BJ, Zhang ZZ. Shenfu injection suppresses apoptosis by regulation of $\mathrm{Bcl}-2$ and caspase-3 during hypoxia/reoxygenation in neonatal rat cardiomyocytes in vitro. Mol Biol Rep 2009:36:365-70

149. Yang B, El Nahas AM, Fisher M, Wagner B, Huang L, Storie I, Barnett D, Barratt J, Smith AC, Johnson TS. Inhibitors directed towards caspase- 1 and -3 are less effective than pan caspase inhibition in preventing renal proximal tubular cell apoptosis. Nephron Exp Nephrol 2004;96:e39-51.

150. Johnstone RW, Frew AJ, Smyth MJ. The TRAIL apoptotic pathway in cancer onset, progression and therapy. Nat Rev Cancer 2008;8:782-98.

151. Kruyt FA. TRAIL and cancer therapy. Cancer Lett 2008;263:14-25

152. Humphreys RC, Halpern W. Trail receptors: targets for cancer therapy. Adv Exp Med Biol 2008;615:127-58

153. Wang S, El-Deiry WS. TRAIL and apoptosis induction by TNF-family death receptors. Oncogene 2003;22:8628-33.

154. Grotzer MA, Eggert A, Zuzak TJ, Janss AJ, Marwaha S, Wiewrodt BR, Ikegaki N Brodeur GM, Phillips PC. Resistance to TRAIL-induced apoptosis in primitive neuroectodermal brain tumor cells correlates with a loss of caspase-8 expression. Oncogene 2000;19:4604-10.

155. Iolascon A, Borriello A, Giordani L, Cucciolla V, Moretti A, Monno F, Criniti V, Marzullo A, Criscuolo M, Ragione FD. Caspase 3 and 8 deficiency in human neuroblastoma. Cancer Genet Cytogenet 2003:146:41-7.

156. Teitz T, Wei T, Valentine MB, Vanin EF, Grenet J, Valentine VA, Behm FG, Look AT Lahti JM, Kidd VJ. Caspase 8 is deleted or silenced preferentially in childhood neuroblastomas with amplification of MYCN. Nat Med 2000:6:529-35.

157. Yang JK. FLIP as an anti-cancer therapeutic target. Yonsei Med J 2008;49:19-27

158. Korkolopoulou P, Saetta AA, Levidou G, Gigelou F, Lazaris A, Thymara I, Scliri M Bousboukea K, Michalopoulos NV, Apostolikas N, Konstantinidou A, Tzivras M, Patsouris E. c-FLIP expression in colorectal carcinomas: association with Fas/FasL expression and prognostic implications. Histopathology 2007:51:150-6.

159. Zou W, Chen S, Liu X, Yue P, Sporn MB, Khuri FR, Sun SY. c-FLIP downregulation contributes to apoptosis induction by the novel synthetic triterpenoid methyl-2cyano-3, 12-dioxooleana-1, 9-dien-28-oate (CDDO-Me) in human lung cancer cells. Cancer Biol Ther 2007;6:1614-20.

160. Roulston A, Marcellus RC, Branton PE. Viruses and apoptosis. Annu Rev Microbiol 1999:53:577-628.

161. Salvesen GS, Duckett CS. IAP proteins: blocking the road to death's door. Nat Rev Mol Cell Biol 2002:3:401-10. 
162. Cassens U, Lewinski G, Samraj AK, von Bernuth H, Baust H, Khazaie K, Los M. Viral modulation of cell death by inhibition of caspases. Arch Immunol Ther Exp 2003;51:19-27.

163. Eckelman BP, Salvesen GS, Scott FL. Human inhibitor of apoptosis proteins: why XIAP is the black sheep of the family. EMBO Rep 2006; 7:988-94

164. Tamm I, Kornblau SM, Segall H, Krajewski S, Welsh K, Kitada S, Scudiero DA, Tudor G, Qui YH, Monks A, Andreeff M, Reed JC. Expression and prognostic significance of IAP-family genes in human cancers and myeloid leukemias. Clin Cancer Res 2000;6:1796-803.

165. Kania J, Konturek SJ, Marlicz K, Hahn EG, Konturek PC. Expression of survivin and caspase-3 in gastric cancer. Dig Dis Sci 2003:48:266-71.

166. Lu S, Zhang B, Wang Z. Expression of survivin, cyclinD1, p21(WAF1), caspase-3 in cervical cancer and its relation with prognosis. J Huazhong Univ Sci Technolog Med Sci 2005:25:78-81.

167. Espinosa M, Cantu D, Herrera N, Lopez CM, De la Garza JG, Maldonado V, Melendez-Zajgla J. Inhibitors of apoptosis proteins in human cervical cancer. BMC Cancer 2006;6:45

168. Giodini A, Kallio MJ, Wall NR, Gorbsky GJ, Tognin S, Marchisio PC, Symons M, Altieri DC. Regulation of microtubule stability and mitotic progression by survivin. Cancer Res 2002;62:2462-7

169. LaCasse EC, Mahoney DJ, Cheung HH, Plenchette S, Baird S, Korneluk RG. IAPtargeted therapies for cancer. Oncogene 2008;27:6252-75.

170. Zhang S, Suvannasankha A, Crean CD, White VL, Johnson A, Chen CS, Farag SS. OSU-03012, a novel celecoxib derivative, is cytotoxic to myeloma cells and acts through multiple mechanisms. Clin Cancer Res 2007;13:4750-8.

171. Carter BZ, Mak DH, Schober WD, McQueen T, Harris D, Estrov Z, Evans RL, Andreeff M. Triptolide induces caspase-dependent cell death mediated via the mitochondrial pathway in leukemic cells. Blood 2006;108:630-7.

172. Carter BZ, Mak DH, Schober WD, Dietrich MF, Pinilla C, Vassilev LT, Reed JC Andreeff M. Triptolide sensitizes AML cells to TRAlL-induced apoptosis via decrease of XIAP and p53-mediated increase of DR5. Blood 2008:111:3742-50.

173. Sekine K, Takubo K, Kikuchi R, Nishimoto M, Kitagawa M, Abe F, Nishikawa K, Tsuruo T, Naito M. Small molecules destabilize cIAP1 by activating autoubiquitylation. J Biol Chem 2008:283:8961-8.

174. Fandy TE, Shankar S, Srivastava RK. Smac/DIABLO enhances the therapeutic potential of chemotherapeutic drugs and irradiation, and sensitizes TRAIL-resistant breast cancer cells. Mol Cancer 2008; 7:60.

175. Fulda S, Wick W, Weller M, Debatin KM. Smac agonists sensitize for Apo2L/TRAILor anticancer drug-induced apoptosis and induce regression of malignant glioma in vivo. Nat Med 2002;8:808-15.

176. Yang L, Mashima T, Sato S, Mochizuki M, Sakamoto H, Yamori T, Oh-Hara T, Tsuruo T. Predominant suppression of apoptosome by inhibitor of apoptosis protein in non-small cell lung cancer $\mathrm{H} 460$ cells: therapeutic effect of a novel polyarginineconjugated Smac peptide. Cancer Res 2003;63:831-7.

177. Arnt CR, Chiorean MV, Heldebrant MP, Gores GJ, Kaufmann SH. Synthetic Smac/ DIABLO peptides enhance the effects of chemotherapeutic agents by binding XIAP and CIAP1 in situ. J Biol Chem 2002;277:44236-43

178. LaCasse EC, Cherton-Horvat GG, Hewitt KE, Jerome LJ, Morris SJ, Kandimalla ER, Yu D, Wang H, Wang W, Zhang R, Agrawal S, Gillard JW, Durkin JP. Preclinical characterization of AEG35156/GEM 640, a second-generation antisense oligonucleotide targeting X-linked inhibitor of apoptosis. Clin Cancer Res 2006;12:5231-41.

179. Carter BZ, Gronda M, Wang Z, Welsh K, Pinilla C, Andreeff M, Schober WD, Nefzi A, Pond GR, Mawji IA, Houghten RA, Ostresh J, Brandwein J, Minden MD, Schuh AC, Wells RA, Messner H, Chun K, Reed JC, Schimmer AD. Small-molecule XIAP inhibitors derepress downstream effector caspases and induce apoptosis of acute myeloid leukemia cells. Blood 2005;105:4043-50.

180. Karikari CA, Roy I, Tryggestad E, Feldmann G, Pinilla C, Welsh K, Reed JC, Armour EP, Wong J, Herman J, Rakheja D, Maitra A. Targeting the apoptotic machinery in pancreatic cancers using small-molecule antagonists of the X-linked inhibitor of apoptosis protein. Mol Cancer Ther 2007;6:957-66.

181. Rodel F, Frey B, Leitmann W, Capalbo G, Weiss C, Rodel C. Survivin antisense oligonucleotides effectively radiosensitize colorectal cancer cells in both tissue culture and murine xenograft models. Int J Radiat Oncol Biol Phys 2008;71:247-55.

182. Fortugno P, Beltrami E, Plescia J, Fontana J, Pradhan D, Marchisio PC, Sessa WC, Altieri DC. Regulation of survivin function by Hsp90. Proc Natl Acad Sci USA 2003;100:13791-6.

183. Plescia J, Salz W, Xia F, Pennati M, Zaffaroni N, Daidone MG, Meli M, Dohi T, Fortugno P, Nefedova Y, Gabrilovich DI, Colombo G, Altieri DC. Rational design of shepherdin, a novel anticancer agent. Cancer Cell 2005;7:457-68.
184. Liu O, Fu H, Xing R, Tie Y, Zhu J, Sun Z, Zheng X. Survivin knockdown combined with apoptin overexpression inhibits cell growth significantly. Cancer Biol Ther 2008; 7:1053-60

185. Panigrahi S, Klonisch T, Los M. The art of killing: double stroke with apoptin and survivin as a novel approach in cancer therapy. Cancer Biol Ther 2008;7:1061-2.

186. Pennati M, Binda M, Colella G, Folini M, Citti L, Villa R, Daidone MG, Zaffaroni N Radiosensitization of human melanoma cells by ribozyme-mediated inhibition of survivin expression. J Invest Dermatol 2003;120:648-54.

187. Pennati M, Binda M, Colella G, Zoppe M, Folini M, Vignati S, Valentini A, Citti L, De Cesare M, Pratesi G, Giacca M, Daidone MG, Zaffaroni N. Ribozyme-mediated inhibition of survivin expression increases spontaneous and drug-induced apoptosis and decreases the tumorigenic potential of human prostate cancer cells. Oncogene 2004;23:386-94.

188. Choi KS, Lee TH, Jung MH. Ribozyme-mediated cleavage of the human survivin mRNA and inhibition of antiapoptotic function of survivin in MCF-7 cells. Cancer Gene Ther 2003;10:87-95.

189. Jiang X, Kim HE, Shu H, Zhao Y, Zhang H, Kofron J, Donnelly J, Burns D, Ng SC, Rosenberg S, Wang X. Distinctive roles of PHAP proteins and prothymosin-alpha in a death regulatory pathway. Science 2003;299:223-6.

190. Zhang HZ, Kasibhatla S, Wang Y, Herich J, Guastella J, Tseng B, Drewe J, Cai SX Discovery, characterization and SAR of gambogic acid as a potent apoptosis inducer by a HTS assay. Bioorg Med Chem 2004;12:309-17.

191. Putt KS, Chen GW, Pearson JM, Sandhorst JS, Hoagland MS, Kwon JT, Hwang SK Jin H, Churchwell MI, Cho MH, Doerge DR, Helferich WG, Hergenrother PJ. Smallmolecule activation of procaspase-3 to caspase-3 as a personalized anticancer strategy. Nat Chem Biol 2006:2:543-50.

192. Svingen PA, Loegering D, Rodriquez J, Meng XW, Mesner PW Jr, Holbeck S, Monks A, Krajewski S, Scudiero DA, Sausville EA, Reed JC, Lazebnik YA, Kaufmann $\mathrm{SH}$. Components of the cell death machine and drug sensitivity of the National Cancer Institute Cell Line Panel. Clin Cancer Res 2004;10:6807-20.

193. Maddika S, Ande SR, Panigrahi S, Paranjothy T, Weglarczyk K, Zuse A, Eshraghi M, Manda KD, Wiechec E, Los M. Cell survival, cell death and cell cycle pathways are interconnected: Implications for cancer therapy. Drug Resist Updat 2007;10:13-29.

194. Maddika S, Ande SR, Wiechec E, Hansen LL, Wesselborg S, Los M. Akt-mediated phosphorylation of CDK2 regulates its dual role in cell cycle progression and apoptosis. J Cell Sci 2008;121:979-88.

195. Mandruzzato S, Brasseur F, Andry G, Boon T, van der Bruggen P. A CASP-8 mutation recognized by cytolytic $T$ lymphocytes on a human head and neck carcinoma. J Exp Med 1997;186:785-93.

196. Shin MS, Kim HS, Kang CS, Park WS, Kim SY, Lee SN, Lee JH, Park JY, Jang JJ, Kim CW, Kim SH, Lee JY, Yoo NJ, Lee SH. Inactivating mutations of CASP10 gene in non-Hodgkin lymphomas. Blood 2002;99:4094-9.

197. Srinivasula SM, Ahmad M, Guo Y, Zhan Y, Lazebnik Y, Fernandes-Alnemri T, Alnemri ES. Identification of an endogenous dominant-negative short isoform of caspase-9 that can regulate apoptosis. Cancer Res 1999:59:999-1002.

198. Glogowska A, Pyka J, Kehlen A, Los M, Perumal P, Weber E, Cheng SY, Hoang-Vu $\mathrm{C}$, Klonisch $\mathrm{T}$. The cytoplasmic domain of proEGF negatively regulates motility and elastinolytic activity in thyroid carcinoma cells. Neoplasia 2008:10:1120-30.

199. Hashemi M, Ghavami S, Eshraghi M, Booy EP, Los M. Cytotoxic effects of intra and extracellular zinc chelation on human breast cancer cells. Eur J Pharmacol 2007:557:9-19.

200. Zuse A, Prinz H, Muller K, Schmidt P, Gunther EG, Schweizer F, Prehn JH, Los M. 9 Benzylidene-naphtho[2,3-b]thiophen-4-ones and benzylidene-9(10H)-anthracenones as novel tubulin interacting agents with high apoptosis-inducing activity. Eur J Pharmacol 2007;:575:34-45

201. Maddika S, Bay GH, Kroczak TJ, Ande SR, Maddika S, Wiechec E, Gibson SB, Los $M$. Akt is transferred to the nucleus of cells treated with apoptin, and it participates in apoptin-induced cell death. Cell Prolif 2007;40:835-48.

202. Maddika S, Wiechec E, Ande SR, Poon IK, Fischer U, Wesselborg S, Jans DA Schulze-Osthoff K, Los M. Interaction with PI3-kinase contributes to the cytotoxic activity of apoptin. Oncogene 2008:27:3060-5.

203. Ghavami S, Rashedi I, Dattilo BM, Eshraghi M, Chazin WJ, Hashemi M Wesselborg S, Kerkhoff C, Los M. S100A8/A9 at low concentration promotes tumor cell growth via RAGE ligation and MAP kinase-dependent pathway. J Leukoc Biol 2008;83:1484-92.

204. Hombach-Klonisch S, Panigrahi S, Rashedi I, Seifert A, Alberti E, Pocar P, Kurpisz M, Schulze-Osthoff K, Mackiewicz A, Los M. Adult stem cells and their transdifferentiation potential-perspectives and therapeutic applications. J Mol Med 2008;86:1301-14.

205. Alexander HK, Booy EP, Xiao W, Ezzati P, Baust H, Los M. Selected technologies to control genes and their products for experimental and clinical purposes. Arch Immunol Ther Exp 2007;55:139-49. 